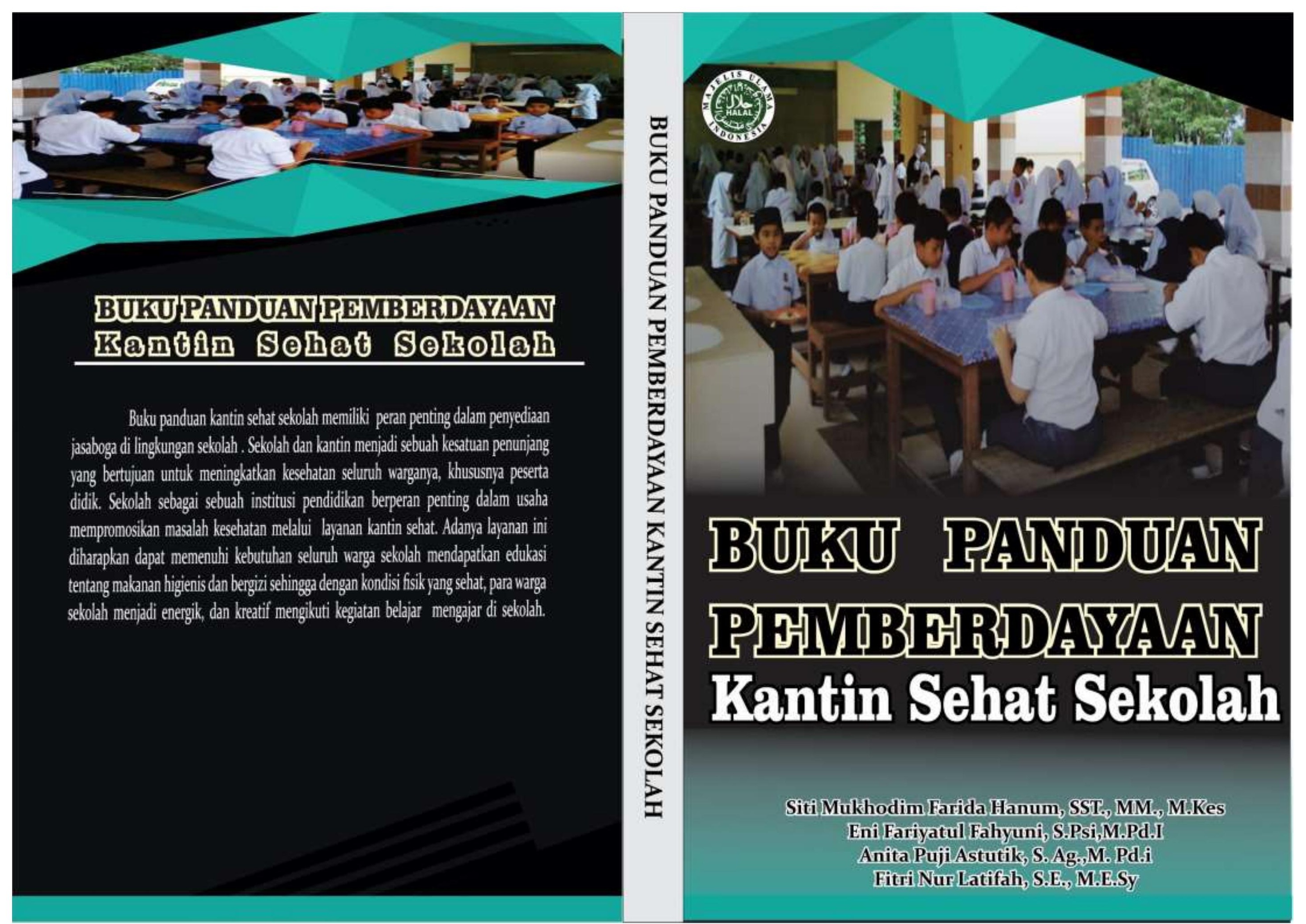





\title{
BUKU PANDUAN \\ PEMBERDAYAAN KANTIN SEHAT SEKOLAH
}

\author{
Penulis
}

Siti Mukhodim Farida Hanum,SST., MM., M.Kes

Eni Fariyatul Fahyuni, S.Psi., M.Pd.I

Anita Puji Astutik, S.Ag., M.Pd.I

Fitri Nur Latifah,S.E., M.E.Sy

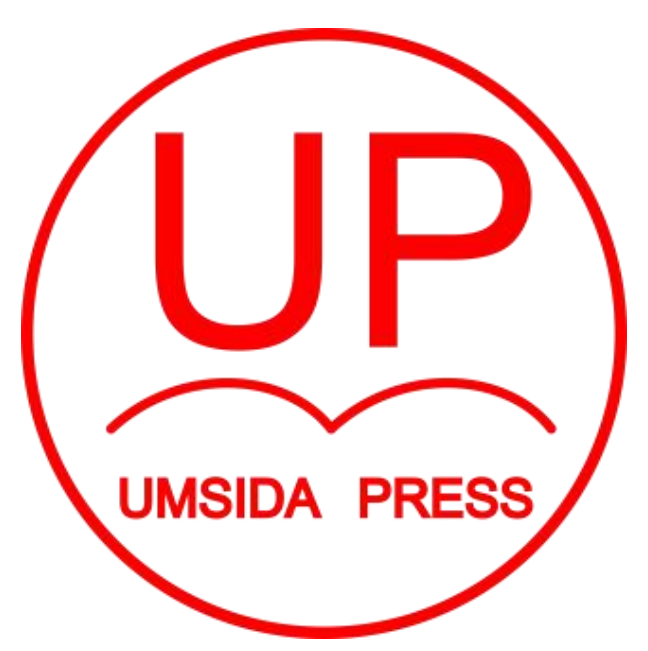

Diterbitkan oleh

UMSIDA PRESS

Jl. Mojopahit 666 B Sidoarjo

ISBN: 978-602-5914-56-0

Copyright $(2019$.

\section{Authors}

All rights reserved 


\section{BUKU PANDUAN \\ PEMBERDAYAAN KANTIN SEHAT SEKOLAH}

\section{Penulis :}

Siti Mukhodim Farida Hanum, SST., MM., M.Kes

Eni Fariyatul Fahyuni, S.Psi., M.Pd.I

Anita Puji Astutik, S.Ag., M.Pd.I

Fitri Nur Latifah,S.E., M.E.Sy

ISBN :

978-602-5914-56-0

\section{Editor :}

Eni Fariyatul Fahyuni, S.Psi., M.Pd.I

Design Sampul dan Tata Letak :

Ahmad Falahi

\section{Penerbit :}

UMSIDA Press

\section{Redaksi :}

Universitas Muhammadiyah Sidoarjo

Jl. Mojopahit No 666B

Sidoarjo, Jawa TImur

Cetakan pertama, Maret 2019

(C) Hak cipta dilindungi undang-undang

Dilarang memperbanyak karya tulis ini dengan suatu apapun tanpa ijin tertulis dari penerbit. 


\section{Kata Pengantar}

Segala puji hanya milik Allah SWT. Shalawat dan salam selalu tercurahkan kepada Rasulullah SAW. Berkat limpahan dan rahmat-Nya sehingga penulis mampu menyelesaikan buku panduan "Pemberdayaan Kantin Sehat Sekolah" yang tentunya diharapkan dapat memberikan kontribusi positif bagi pembaca dan pemerhati pendidikan khususnya bagi para siswa, guru, maupun calon pendidik di sekolah.

Sejauh ini sekolah masih menjadi tempat penyampaian ilmu pengetahuan tentang jajanan sehat. Namun, pengetahuan tersebut hanya sebatas pada edukasi semata tentang pengenalan berbagai jenis makanan dan jajanan serta lingkungan sehat. Materi jajanan dan layanan kantin sehat belum menjadi bagian integral yang erat dengan kurikulum sekolah. Untuk itu perlunya inovasi kentin sehat islami di sekolah dengan konsep pemberdayaan warga sekolah agar menjadi cerdas dalam berkonsumsi sesuai dengan standar kesehatan

Akhir kata penulis menyampaikan ucapan terima kasih atas motivasi dan bantuan yang diberikan. Mudah-mudahan karya sederhana ini bermanfaat dan dicatat sebagai amal kebajikan di sisiNya. Amin.

Sidoarjo, 16 Maret 2019

Penulis 
DAFTAR ISI

Kata Pengantar

Daftar isi

Bab I : Mengenalkan Makanan Higienis
A. Makanan Sehat
B. Kantin Sekolah ----------------------------------------------------------------- 4
C. Kantin Sehat Sekolah ---_-_-_-_- 6

Bab II : Pemberdayaan Kantin Sehat
A. Pemberdayaan Kantin Sehat
B. Perencanaan Kantin Sehat di Sekolah
C. Peran Kelembagaan Pengembangan Kantin Sehat
D. Pengembangan Kantin Sehat

Lampiran

A. Pedoman Persyaratan Hygiene Sanitasi Makanan Jajanan Menteri Kesehatan

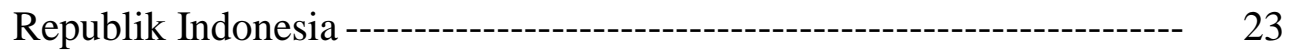

B. Pembinaan dan Pengawasan Sanitasi Makanan Jajanan ------------------ 30

C. Pedoman Penyelenggaraan Kursus Hygiene Sanitasi Makanan --------- 32

D. Kurikulum Kursus Hygiene Sanitasi Makanan Bagi Penanggungjawab Makanan --------------------------------------------------------------------- 35

E. Kurikulum Kursus Hygiene Sanitasi MakananBagi Penjamah Makanan

F. Kurikulum Kursus Hygiene Sanitasi Makanan Bagi Penanggungjawab

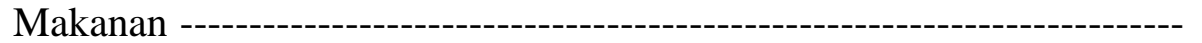

G. Sertifikat Khusus Hygiene Sanitasi Makanan Bagi Penanggungjawab Makanan ----------------------------------------------------------------------- 39

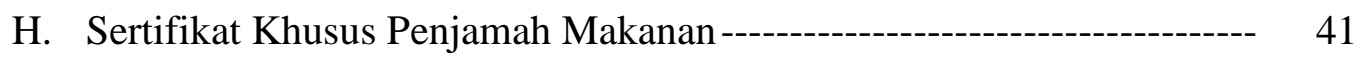

Daftar Pustaka 


\section{BAB I \\ MENGENALKAN MAKANAN HIGIENIS}

\section{A. Makanan Sehat}

Beragam jenis makanan jajanan di sekolah berkembang sangat pesat sejalan dengan pesatnya pembangunan. Makanan jajanan sebagai makanan siap makan atau dipersiapkan untuk dikonsumsi langsung dilokasi jualan, jalanan atau tempat umum, seperti area permukiman, pusat perbelanjaan, terminal, pasar. dan sekolah. Makanan jajanan menurut food and agricultural organization (FAO) adalah makanan dan minuman yang dipersiapkan dan dijual oleh pedagang kaki lima di jalanan dan di tempat-tempat keramaian lainnya yang dapat langsung dimakan atu dikonsumsi tanpa pengolahan atau persiapan lebih lanjut. Istilah makanan jajanan tidak jauh dari istilah junk food, fast food, dan street food karena istilah tersebut merupakan bagian dari istilah makanan jajanan (Aprillia, 2011). Makanan jajanan terdiri dari minuman, makanan kecil (kudapan), dan makanan lengkap, didefinisikan sebagai makanan yang siap untuk dimakan atau terlebih dahulu dimasak di tempat penjualan, dan di jual di pinggir jalan, atau tempat umum (Winarno, 1993).

Salah satu upaya guna meningkatkan kualitas sumber daya manusia pada anak sekolah adalah dengan menyediakan makanan jajanan yang bergizi guna memenuhi kebutuhan tubuh selama mengikuti pelajaran di sekolah. Anak-anak mempunyai sifat yang berubah-ubah terhadap makanan. Seringkali anak memilih makanan yang salah terlebih lagi jika tidak dibimbing oleh orang tuanya. Selain itu anak lebih sering menghabiskan waktu diluar rumah sehingga anak lebih sering menemukan aneka jajanan baik yang dijual disekitar sekolah, lingkungan bermain ataupun pemberian teman. Siswa merupakan konsumen makanan aktif dan mandiri dalam menentukan jajanan makanan yang dikehendakinya. Semua anak sekolah umumnya setiap hari menghabiskan sepertiga waktunya di sekolah dan mendapat peluang yang lebih banyak memperoleh makanan, terutama yang diperolehnya di luar rumah sebagai makanan jajanan. Mereka memiliki kebebasan menggunakan uang jajan mereka untuk makanan dan minuman sesuai dengan selera mereka sendiri.

Anak usia sekolah adalah investasi masa depan sebagai generasi penerus bangsa. Kualitas bangsa di masa depan ditentukan kualitas anak-anak saat ini. Untuk itu sebagai upaya yang dapat dilakukan dalam meningkatkan kualitas sumber daya manusia harus dilakukan sejak dini, sistematis dan berkesinambungan. Tumbuh berkembangnya anak usia sekolah yang optimal tergantung pada pemberian nutrisi dengan kualitas dan kuantí́tas yang baik serta benar. 
Salah satu masalah kesehatan yang dapat terjadi akibat mengonsumsi makanan adalah keracunan makanan. Berdasarkan data dari Sentra Informasi Keracunan (SIKer) Nasional Badan POM (2014) diketahui bahwa kejadian keracunan yang terjadi akibat pangan pada Bulan Januari-Maret 2014 sebanyak 29 insiden. SIKer Nasional Badan POM juga mencatat bahwa pada tahun 2014, jumlah insiden keracunan siswa akibat makanan berada pada posisi teratas dari keseluruhan kasus keracunan nasional. Kasus keracunan dan diare dapat disebabkan oleh adanya pencemaran makanan jajanan, baik yang disebabkan oleh faktor fisik, kimiawi maupun biologis. Kontaminasi fisik berupa masuknya benda asing yang bukan bagian dari bahan makanan, sedangkan kontaminasi kimiawi adalah adanya berbagai unsur kimia yang terlarut dalam makanan yang menimbulkan pencemaran pada bahan makanan, dan kontaminasi biologis yaitu adanya organisme hidup yang masuk dan bersarang dalam makanan dan menimbulkan kontaminan di dalamnya (Purnawijayanti, 2001).

Peredaran makanan jajanan sehat di sekolah yang diharapkan keberadaanya melibatkan banyak pihak baik dari produsen, penjual, pimpinan sekolah, siswa, dan pemerintah selaku pemegang regulasi tertinggi. Untuk mencapai target ketersediaan makanan jajanan yang sehat dan higienis di sekolah, perlunya peningkatan kapasitas atau pemahaman sumber daya pangan jajanan bagi anak sekolah itu sendiri, modeling dan replikasi kantin sehat sekolah yang dibangun oleh sekolah, dan optimalisasi manajemen sekolah dengan mengadakan atau membentuk Aksi Nasional Pangan Jajanan Anak Sekolah (PJAS). Target aksi tersebut bertujuan meningkatkan pemahaman, ketrampilan, dan proporsi konsumsi jajanan anak sekolah yang memenuhi syarat keamanan, mutu, dan gizi yang sudah terstandarisasi.

Makanan sehat adalah makan yang mengandung zat-zat yang dibutuhkan oleh tubuh dan harus memiliki beberapa syarat, yaitu higienis, bergizi dan berkecukupan, tetapi tidak harus makanan mahal dan enak. Makanan higienis adalah makanan yang tidak terkena kuman atau zat yang dapat mengganggu kesehatan. Makanan bergizi adalah makanan yang memiliki jumlah kandungan karbohidrat, protein, lemak dan vitamin yang cukup untuk tubuh. Sedangkan makanan berkecukupan adalah makanan yang sesuai dengan kebutuhan berdasarkan usia dan kondisi tubuh. Selain persyaratan di atas, makanan sehat itu dipengaruhi oleh cara memasaknya, suhu makanan pada saat penyajian dan bahan makanan yang mudah dicerna. Tujuan dari memakan makanan yang sehat bagi tubuh adalah untuk menjaga agar badan tetap sehat, tumbuh dan berkembang dengan baik. Sedangkan apabila tidak terpenuhi syarat - syarat tersebut, bukan kesehatan yang didapat tetapi malah terbentuk panyakit.

Makanan yang tidak sehat dan tidak aman dikonsumsi anak-anak di sekolah bisa berasal dari bahan pangan yang tercemar, proses pengolahan dan penyimpanan makanan yang tidak higienis, atau proses penyajian dan kemasan yang kurang baik. Oleh karenanya kantin sekolah berperan penting dalam penyajian makanan yang sehat dan 
aman untuk siswa dan warga sekolah lainnya. Pengembangan kantin sehat di sekolah perlu dilakukan, karena keberadaan kantin memegang peranan penting dalam pengembangan budaya makan sehat para warganya. Kantin memiliki peranan penting sebagai penyedia utama makanan di sekolah selain itu sebagai edukasi atau sosialisasi dalam rangka membentuk pembiasaan pola makan makanan siswa yang sehat sejak dini (Patricia et.al., 2014).

Kebiasaan mengkonsumsi makanan jajanan sudah tidak asing terjadi dikalangan siswa di sekolah. Kebiasaan mereka jajan sembarangan tersebut sangat sulit untuk dihilangkan karea sudah membudayanya dalam setiap aktivitas mereka sehari-hari di sekolah. Siswa utamnya yang masih anak-anak atau bahkan remaja sekalipun biasanya makanan jajanan yang mereka sukai dan konsumsi adalah makanan dengan warna, penampilan, tekstur, aroma dan rasa yang menarik. Jajanan yang kandungan zat gizinya kurang beragam yaitu hanya terdiri dari karbohidrat saja atau karbohidrat dan lemak (minyak) tidak mereka pertimbangkan dampak negatifnya bagi kesehatan. Makanan jajanan yang ditawarkan di sekolah pun saat ini banyak yang belum sesuai dengan ketentuan bergizi dan menyehatkan, karena kebanyakan dari para penjual makanan jajanan sekolah banyak yang belum sepenuhnya memperhatikan kebersihan, keamanan dan kandungan gizi makanan yang dijajakan. Faktor ekonimislah yang akhirnya menjadi pertimbangan untuk mendapatkan keuntungan yang sebesar-besarnya bagi penjual kantin di sekolah.

Peningkatan derajat kesehatan warga sekolah ini sangat dipengaruhi oleh faktor perilaku yaitu perilaku yang proaktif warganya untuk memelihara, menjaga dan meningkatkan kesadaran akan kesehatan, mencegah risiko terjadinya penyakit berbahaya, melindungi diri dari ancaman penyakit serta berpartisipasi aktif dalam kegiatan pemberdayaan masyarakat sekolah yang dikenal dengan Program Perilaku Hidup Bersih dan Sehat (PHBS) di sekolah. Pelaksanaan program PHBS adalah salah satu upaya untuk memberi pengalaman belajar atau menciptakan kondisi bagi perorangan, keluarga, kelompok dan masyarakat dengan membuka jalur komunikasi, memberikan informasi dan melakukan edukasi untuk meningkatkan pengetahuan, sikap dan perilaku mereka tentang pentingnya menjaga pola hidup bersih dan sehat. Program PHBS ini dapat dilakukan secara serentak di seluruh kantin-kantin di sekolah tentunya melalui pendekatan pimpinan, bina usaha dan pemberdayaan kesadaran masyarakat sekolah terhadap jajanan makanan yang mereka konsumsi setiap harinya (Depkes, 2008)

Sampel penelitian ini dilakukan di kantin SMPN 1 Porong dan SMPN 2 Porong, dimana keduanya merupakan sekolah yang sebagian besar muridnya berasal dari kalangan menengah ke atas dan lokasi sekolah ini terletak dekat dengan pinggiran jalan raya Porong yang ramai dan padat, dimana disetiap tempat-tempat jajanan mudah sekali ditemui dan penjualan fast food mudah didapat dan jumlahnya sangat beragam. 


\section{B. Kantin Sekolah}

Kantin sekolah merupakan suatu tempat yang digunakan untuk memasak atau membuat makanan dan selanjutnya dihidangkan kepada para konsumennya. Keberadaan kantin sekolah memberikan peranan penting karena mampu menyediakan lebih dari seperempat konsumsi makanan sekaligus berbagai penyakit yang medianya melalui makanan dan minuman. Dengan demikian makanan dan minuman yang dijual di kantin bisa juga berpotensi menyebabkan penyakit bawaan makanan apabila tidak dikelola, dikemas dan ditanganisecara baik dan benar (Mukono, 2000).

Kantin sekolah memiliki peran penting dalam penyediaan jasa boga di lingkungan sekolah untuk memenuhi kebutuhan jajan anak, guru, dan para warga sekolah lainnya pada saat jam sekolah. Penerapan higienis sanitasi yang baik pada kantin di sekolah akan mencegah terjadinya kontaminasi pada makanan, seperti penelitian yang dilakukan oleh Pratiwi (2014) yang menunjukkan bahwa

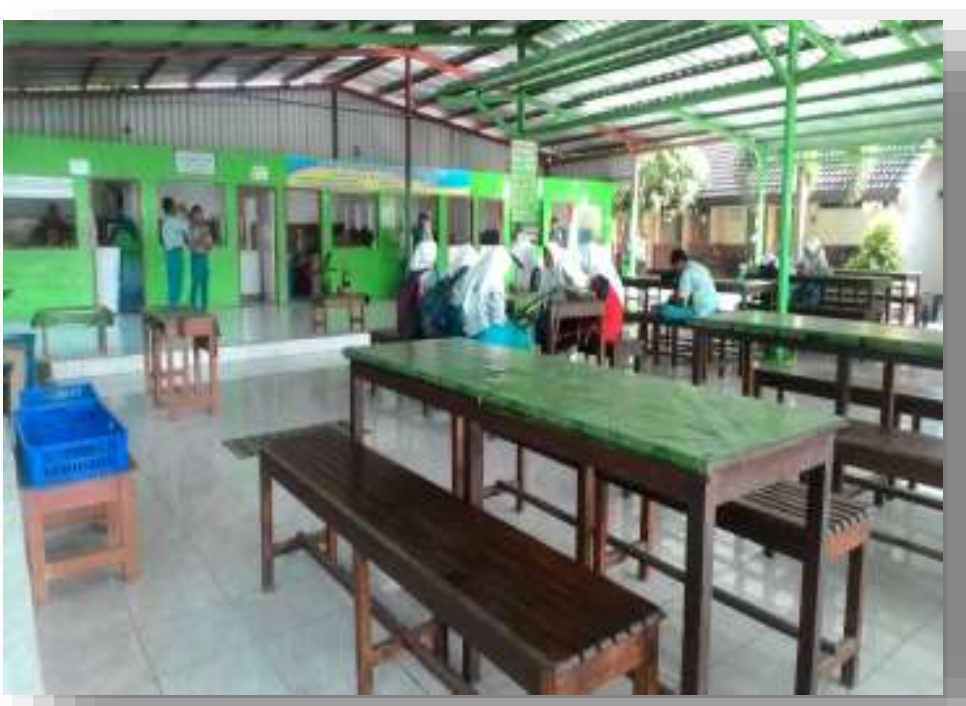

Gambar 1.1 Kantin SMPN 2 Porong ada hubungan antara praktik mencuci tangan memakai sabun, pencucian bahan mentah dan sanitasi peralatan dengan kandungan E. coli pada sambal yang disediakan di kantin. Penelitian yang dilakukan oleh Tofani (2007) bahwa kondisi sanitasi pedagang makanan jajanan di SDN Kalisari II masih kurang, yaitu sarana pembuangan sampah yang tidak tertutup, pembuangan limbah yang masih terbuka, tergenang dan becek. Kondisi sanitasi tempat makanan juga susah dibersihkan dan pencucian alat masih kurang baik.

Sampel pada penelitian ini terdiri dari 2 kantin sekolah, yakni: kantin SMPN 1 Porong dan kantin SMPN 2 Porong Kecamatan Porong, Kabupaten Sidoarjo. penelitian ini dilakukan karena mengingat faktor kesehatan anak sekolah menjadi prioritas yang mendapat sorotan tajam dari pemerintah pada saat ini. Dari hasil sensus penduduk pada tahun 2013 didapatkan data bahwa kelompok usia anak sekolah di Indonesia berjumlah sekitar 66 juta jiwa atau 28\% dari jumlah penduduk keseluruhan di Indonesia. Karena itu, sekolah sebagai sebuah institusi pendidikan berperan penting dalam usaha promosi kesehatan dan edukasi pemahman mengkonsumsi jajanan makanan yang mereka konsumsi setiap harinya, hal ini karena sebagian besar anak usia sekolah menghabiskan 4-8 jam sehari berada di lingkungan sekolah. Salah satu komponen penting dalam melaksanakan usaha kesehatan sekolah yaitu melalui layanan kantin sehat. Keberadaan 
kantin di sekolah adalah suatu bentuk usaha yang dilakukan sekolah untuk memberikan pelayanan kepada para siswa, warga sekolah dan atau unsur sekolah lainnya yang membutuhkan makanan maupun minuman sehat sehingga kegiatan belajar mengajar di sekolah dapat berjalan dengan baik (Kusmintardjo, 1993).

\section{Kantin Sehat Sekolah}

Kantin sekolah berhubungan erat dengan penyediaan makanan jajanan sehat untuk anak. Pemerintah daerah dalam hal ini Dinas Kesehatan Kota/Kabupaten telah banyak berperan dalam mengembangkan pemberdayaan masyarakat baik itu produsen makanan dan juga konsumennya. Namun, selama ini program-program tersebut lebih banyak diarahkan pada produsen atau pengusaha. Program-program pemberdayaan pada anak dan warga di sekolah kurang mendapat perhatian, pelaksanaan programnya kurang terpola dan belum berkelanjutan. Program-program yang disediakan untuk sekolah masih terbatas pada uji sampel jajanan dan diseminasi hasilnya kepada kepala sekolah. Dengan demikian edukasi terhadap pemberdayaan masyarakat akan pentingnya kantin sekolah belum sampai pada lapisan bawah, dalam hal ini baik konsumen maupun produsesn daripada lembaga itu sendiri, yakni sekolah.

Menurut Anzarkusuma, dkk. (2014) pentingnya sosialisasi pemberian edukasi melalui sosialisasi hidup sehat, pembiasaan sarapan dan membawa bekal ke sekolah akan berdampak pada pemahaman positif anak selanjutnya yang akan dapat memperbaiki pola makan anak menjadi pola makan sehat dan dengan gizi seimbang. Di tengah keprihatinan terhadap pengelolaan layanan kantin yang masih menjual makanan dan minuman yang kurang sehat, SMPN 2 Porong merupakan salah satu sekolah yang memberikan layanan kantin sehat sebagai upaya sekolah dalam meningkatkan derajat kesehatan warga sekolahnya dan wadah pendidikan dengan memberikan pemahaman tentang kesehatan secara nyata dengan menyediakan makanan ataupun minuman yang meminimalisasikan penggunaan zat aditif pada makanan dan SMPN 1 Porong sebagai mitra dalam pemberdayaan masyarakat akan pentingnya membangun, menciptakan, dan melaksanakan program kantin sehat ini merupakan sekolah yang bisa melanjutkan penerapan kantin sehat yang selama ini dilaksanakan oleh SMPN 2 Porong yang tentunya perlu dimaksimalkan keduanya terhadap standarisasi faktor kesehatan yang ditetapkan oleh pemerintah, dalam hal ini lembaga dinas Kementrian Kesehatan.

Sekolah dan kantin merupakan kesatuan penunjang kesehatan anak di sekolah. Sekolah dan kantin memiliki peran yang sangat penting. Sejauh ini sekolah masih menjadi tempat penyampaian ilmu pengetahuan tentang jajanan sehat. Namun, pengetahuan tersebut sebatas pada informasi dari guru di kelas misalnya dari mata pelajaran Penjaskes (pendidikan jasmani dan kesehatan) atau dari IPA (Ilmu Pengetahuan Alam). Sejauh ini belum ada satu materi yang lengkap tentang konsumsi makanan, jajanan dan lingkungan sehat. Beberapa negara lain misalnya Australia, USA dan negara di Eropa, 
materi jajanan sehat menjadi bagian dari kurikulum yang dituangkan pada mata pelajaran yang diberikan siswa di sekolah.

Pengembangan kurikulum berkaitan erat dengan tujuan pendidikan. Sanjaya (2011) mengemukakan beberapa aspek yang melandasi kurikulum diantaranya: landasan filosofi, landasan psikologis, landasan sosiologis, dan landasan teknologis. Landasan filosofis menjadi dasar dalam menentukan tujuan pendidikan dan sebagai proses berpikir. Landasan psikologis terkait erat dengan kurikulum yang dikembangkan harus memperhatikan kondisi psikologi perkembangan dan psikologi belajar anak. Landasan sosial budaya berhubungan dengan perubahan sosial budaya masyarakat menyangkut pola hidup masyarakat dan perubahan kehidupan sosial politik. Landasan teknologi menyangkut bahwa ilmu pengetahuan bukan hanya sekedar untuk diketahui, melainkan dapat membentuk ketrampilan tertentu sehingga berdasarkan ketrampilan tersebut dapat membentuk sikap tertentu kepada diri sendiri, orang lain, dan Tuhan Yang Maha Esa.

Saat ini banyak lembaga ataupun perusahaan telah berkolaborasi dengan sekolah, tetapi dalam konteks 'semi promosi' bukan sebagai bentuk pemberdayaan. Sebagai contoh produsen dan pemasar produk susu dalam kemasan menstimulasi siswa untuk membeli produknya dengan memberikan hadiah-hadiah kecil. Farnsworth dan Dunoskovich pada tahun 2001 menemukan fakta bahwa anak yang dilatih keterampilan berkonsumsi lebih baik dan lebih sehat daripada yang tidak terlatih. Anak yang berdaya akan memiliki daya tawar yang tinggi akan produk makanan yang dibeli sehingga mampu memilih dan memilah makanan yang sehat atau tidak. Dalam jangka panjang anak yang berdaya dapat meminimalisir kasus-kasus yang merugikan anak misalnya masalah kesehatan, pemilihan makanan sehat, konsumsi sayur dan buah dan sebagainya.

Pengembangan kantin sehat tentu tidak terlepas dari peran berbagai pihak dan lingkungan sekolah dalam mensosialisasikan serta menginternalisasikannya kepada para siswanya. Pengembangan kantin sehat di Indonesia pada umumnya memiliki bentuk dan layanan yang sangat beragam. Beberapa sekolah dengan kategori Adiwiyata memiliki kantin yang bersih dan memiliki fasilitas yang memadai misalnya tempat cuci piring dengan air mengalir, tempat cuci tangan, tempat sampah yang bersih dan tempat duduk yang lapang. Namun, tidak sedikit tempat kantin sekolah dasar yang belum layak dari segi ketersediaan fasilitas dan kebersihannya.

Pedagang Kaki Lima (PKL) menjadi satu topik dan fenomena yang sangat luas. PKL jajanan depan sekolah dapat menjadi masalah bagi kesehatan anak ketika jajanan yang dijual tidak mengandung nilai gizi dan atau mengandung bahan tambahan yang berbahaya bagi kesehatan anak. Banyak faktor yang dapat mendorong anak membeli jajanan sembarangan adalah faktor produk jajanan itu sendiri, guru di sekolah, pengkondisian dalam keluarga, peran orang tua dan faktor internal anak itu sendiri. Unsur makanan jajanan yang mendorong anak membeli jajanan adalah karena harganya 
yang sesuai dengan uang saku dan rasanya yang dianggap enak atau sesuai dengan preferensi anak. Meski memiliki pengetahuan akan produk jajanan, anak cenderung kurang mempertimbangkan masalah higienitas dan gizi makanan. Sementara orang tua kurang memiliki peran dalam membiasakan jajan anak dalam mengkonsumsi jajanan sehat yang benar. 


\section{BAB II \\ PEMBERDAYAAN KANTIN SEHAT}

\section{A. Pemberdayaan Kantin Sehat di Sekolah}

Program pemberdayaan kantin sehat anak sekolah sejauh ini belum tepat sasaran langsung pada siswa dan pada konteks membangun kompetensi anak dalam mengenal dan mampu memilih jajanan yang sehat dan berguna. Sejauh ini sasaran program masih berada di sekitar anak, yakni pada sekolah, kantin dan PKL. Ketidaktepatan sasaran kegiatan pemberdayaan anak terjadi karena beberapa faktor internal pada anak dan anak mengambil keputusan serta faktor pemberi layanan edukasi kesehatan anak, dalam hal ini adalah instansi pemerintah.

Persyaratan sanitasi kantin ini telah dijelaskan dalam Keputusan Menteri Kesehatan Republik Indonesia Nomor 1098/Menkes/SK/VII/2003 tentang kelaikan higiene sanitasi pada rumah makan dan restoran. Persyaratan higiene sanitasi kantin yang harus memenuhi ketentuan yang telah ditetapkan adalah fasilitas sanitasi seperti kualitas lingkungan dan faktor-faktor lingkungan fisik atau sanitasi dasar, sanitasi makanan, sanitasi peralatan dan penjamah makanan. Sanitasi dasar terdiri dari penyediaan air bersih, pembuangan kotoran manusia (jamban), pembuangan air limbah dan pengelolaan sampah (tempat sampah).

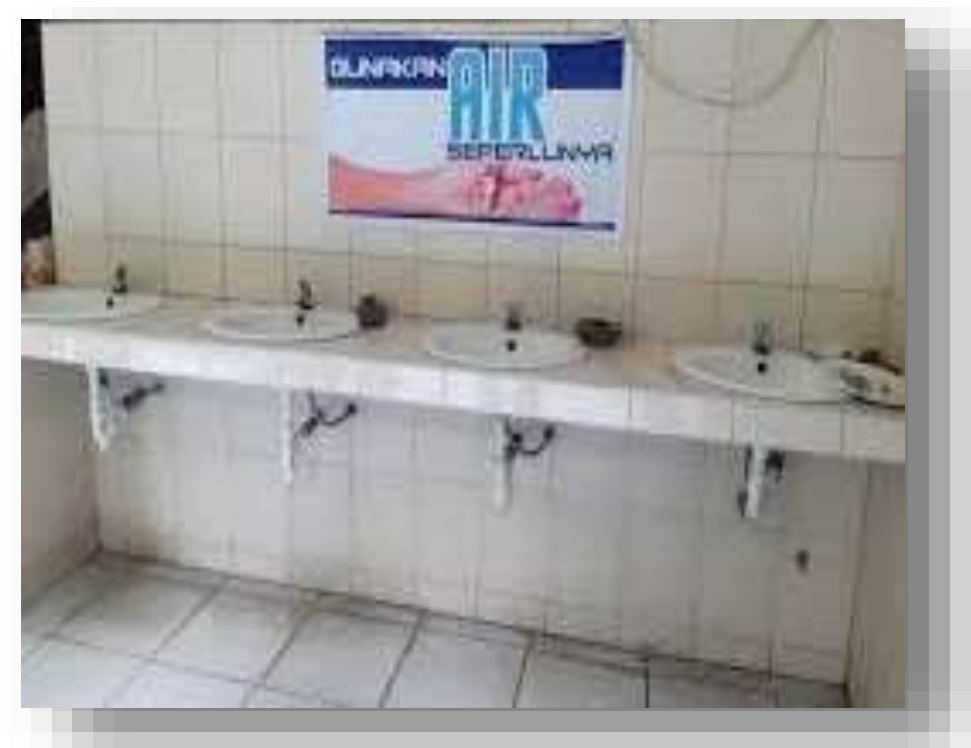

Gambar 2. 1 sanitasi cuci tangan

Untuk meningkatkan kesehatan lingkungan, sanitasi dasar merupakan sarana minimum yang diperlukan sebagai penyediaan lingkungan pemukiman sehat yang memenuhi syarat kesehatan (Azwar, 1995). Tidak hanya di pemukiman, kantin sekolah juga memerlukan sanitasi dasar yang harus dijaga kebersihannya agar dapat mencegah datangnya berbagai faktor penyakit, seperti lalat. Lalat merupakan vektor mekanik yang dapat memindahkan mikroorganisme ke penyediaan makanan seperti kantin sekolah. Apabila kepadatan lalat tinggi, lalat dapat menularkan penyakit tifus abdominalis, disentri, kolera dan penyakit gangguan pencernaan lainnya. Sifat lalat yang suka dengan tempat-tempat yang kotor dan bau perlu diwaspadai sehingga perlu dilakukan sanitasi terhadap lingkungan kantin termasuk sanitasi dasar kantin sekolah (Sumantri, 2010). 
Anak sekolah adalah pihak yang paling sering bersinggungan dengan makanan jajanan. Karena itu, tugas orangtua adalah memberi pengertian kepada anak mengenai makanan jajanan, karena pengetahuan anak mengenai makanan jajanan masih minim. Biasanya mereka membeli pangan jajanan pada penjaja pangan jajanan di sekitar sekolah atau di kantin sekolah. Oleh karena itu, penjaja berperan penting dalam penyediaan pangan jajanan yang sehat dan bergizi serta terjamin keamanannya.

Temuan BPOM dari tahun 2006-2010 menunjukkan, 48\% jajanan anak di sekolah tidak memenuhi syarat keamanan pangan karena mengandung bahan kimia yang berbahaya. Jajanan sekolah mengandung BTP melebihi batas aman serta cemaran mikrobiologi. Berdasarkan pengambilan sampel pangan jajanan anak sekolah yang dilakukan di 6 kota (Jakarta, Serang, Bandung, Semarang, Yogyakarta dan Surabaya), ditemukan 72,08\% positif mengandung zat berbahaya. Selain itu, 45\% makanan jajanan sekolah merupakan makanan jajanan yang berbahaya, adanya cemaran bakteri Escherichia coli pada makanan dan minuman yang dijajakan di sekolah, sebanyak 47,8\% higiene perorangan pedagang tidak baik, sebanyak 62,5\% memiliki sanitasi tidak baik dari segi peralatan, sejumlah 30,4\% pedagang menyajikan makanan tidak baik, dan $47,8 \%$ sarana penjaja tidak baik.

Dalam penelitiannya Triwijayati (2012) diketahui bahwa pengetahuan dan kekhawatiran orang tua menjadi dasar referensi orang tua kepada anak terkait dengan jajanan sehat di sekolah. Kekhawatiran orang tua menjadi bahan yang direferensikan orang tua untuk menambah pengetahuan anak dan referensi orang tua menentukan keputusan pembelian jajanan oleh anak. Dengan kata lain sikap permisif orang tua berhubungan dengan kepatuhan anak dan menentukan pembelian jajanan sekolah. Kebutuhan anak akan jajanan dapat dibedakan menjadi dua yaitu motif fisik dan motif psikis. Kebutuhan fisik ditandai dengan rasa lapar dan haus yang terutama terjadi ketika anak mengeluarkan banyak energi saat bersekolah. Kebutuhan psikis ditandai dengan ketiadaan alasan bagi anak untuk mengkonsumsi jajanan. Anak jajan memang karena ingin jajan dan tidak ada alasan khusus yang mendorong mereka jajan.

Hasil penelitian program pemerintah untuk mengatasi masalah jajanan anak sebenarnya telah banyak dilakukan. Namun, sebagian besar program menunjukkan bahwa fokus kegiatan diarahkan bukan pada pemberdayaan anak namun pada kantin dan sekolah. Realita tersebut terjadi karena permasalahan anak dan keputusan konsumsi jajanan sangat kompleks karena melibatkan pengaruh orang tua, guru, kelompok referensi (teman), dan karakter anak. Selain itu pemerintah daerah sangat terikat dengan tugas pokok dan fungsinya masing-masing dan menghadapi berbagai kendala teknis terkait dengan sumber daya yang ada. Hasil diskusi dengan beberapa dinas terkait dengan masalah anak dan jajanan terungkap bahwa meski banyak program yang ingin diimplementasikan pada anak, kantin dan sekolah, tetapi daya cakupan program masih 
terbatas. Beberapa kegiatan yang diusulkan oleh instansi Pemerintah adalah pembuatan materi pendidikan jajanan sehat untuk anak sekolah.

Materi pendidikan untuk anak sekolah dan orang tua harus mencakup faktor ragam jajanan, jajanan yang berbahaya, dan dampak jajanan bagi kesehatan anak. Selain itu juga perlu adanya materi tentang lingkungan sekitar proses penyiapan dan penyajian jajanan sekolah serta perilaku sehat untuk konsumsi jajanan sekolah. Program tersebut harus melibatkan orang tua sebagai sasaran pendamping karena orang tua berperan penting bagi perkembangan dan kesehatan anak. Dengan demikian untuk dapat memberdayakan anak agar menjadi cerdas dalam berkonsumsi maka diperlukan program lintas sektoral di luar unsur pemerintah yakni sekolah, perusahaan dan orang tua.

\section{B. Perencanaan Program Pengembangan Kantin Sehat Sekolah}

Program pengabdian masyarakat pada pengembangan kantin sehat sekolah dilakukan melalui beberapa tahapan yaitu tahap survey pendahuluan pada bulan Februari hingga Maret 2018, selanjutnya tahap pelaksanaan pada bulan April hingga Juni 2018. Kegiatan selanjutnya akan dilakukan pendampingan hingga bulan September 2018. Tahapan survey pendahuluan dilakukan untuk mengetahui potensi dan analisis kebutuhan dan kelemahan yang dimiliki masing-masing sekolah sebagai lokasi pengabdian. Siswa, guru, penjual makanan sebagai warga sekolah aktif diberi kuesioner untuk mengetahui perilaku makan sehat mereka sebelum ada kegiatan sosialisasi serta pendampingan. Hasil dari kuesioner tersebut digunakan sebagai bahan pengembangan pendidikan perilaku makan sehat. Kegiatan sosialisasi pendidikan perilaku makan sehat dilakukan untuk memberikan wawasan tentang kepentingan PJAS yang sehat, aman, dan bergizi melalui kegiatan penyelenggaraan makanan oleh kantin sekolah menuju kantin sehat dengan mamaksimalkan peran serta seluruh warga sekolah.

Program yang dilaksanakan dalam penelitian pengabdian masyarakat pada pengembangan kantin sehat ini untuk memberdayakan warga sekolah utamanya jajan makanan anak di sekolah antara lain adalah dipaparkan dalam FGD berikut ini:

1. Pembekalan edukasi terhadap pola makan bergizi, jenis-jenis makanan yang dilarang karena mengandung bahan tambahan makanan. Untuk anak sekolah hal tersebut masih agak sulit, namun paling tidak perkenalan tentang zat warna, mereka sudah tahu. Belum ada kemampuan atau daya dari pihak sekolah dalam hal ini SMPN 1 Porong dan SMPN 2 Porong untuk mengutus orang atau pihak kesehatan masyarakat dari puskesmas terdekat dan lainnya untuk memberikan penyuluhan atau TOT karena adanya keterbatasan dana dan biaya. Sekolah di kecamatan Porong Kabupaten Sidoarjo jumlahnya tergolong banyak, namun dalam setahun tidak semua sekolah dapat dilakukan penyuluhan.

2. Monitoring untuk penjualan jajan makanan di kantin. Kebanyakan jajanan untuk anak-anak sekolah ini, jumlah kalorinya itu masih jauh di bawah persyaratan yang 
seharusnya, kandungan gizi dan kehigienisan makanan kurang mendapat perhatian lebih dari pihak produsen, dalam hal ini pihak sekolah yang memiliki lembaga tertinggi. Pentingnya mengedukasi anak-anak dan warga sekolah lainnya supaya mereka dapat memilih makanan yang lebih sehat dan aman.

3. Pemberdayaan kantin sehat dapat dilakukan dengan memberikan penyuluhan ke siswa-siswa yang terlibat dalam organisasi OSIS agar mereka dapat meneruskan informasi dan edukasi yang diberikan ke sesama teman-temannya. Keterlibatan lintas sektoral antara penjual makanan, petugas kesehatan dan warga sekolah khususnya para siswa sebagai pengkonsumsi terbesar di sekolah setiap harinya.

4. Penyuluhan mengenai syarat sanitasi kepada sekolah, melakukan foto dokumentasi sebelum turun mengadakan penyuluhan, dan ternyata yang menjadi masalah adalah kurang adanya tempat untuk mencuci tangan dan ketersediaan pembuangan sampah dan ini juga terjadi di banyak sekolah lainnya.

5. Penyuluhan kepada 7 pedagang selama 2 hari dan memberikan sertifikat bahwa telah mengikuti pelatihan tentang makanan, dan pemberian sertifikat laik higienis kepada warung sekolah yang telah memenuhi syarat checklist uji secara mikrobiologi untuk makanan siap saji dengan menguji bakteri coli.

6. Penyuluhan kepada sekolah-sekolah adhi wiyata, memberikan pembinaan kepada warung-warung di sekolah itu juga kepada penanggung jawab UKS (Usaha Kesehatan Sekolah).

7. Penyuluhan untuk dapur tempat penyiapan makanan yang bersih dan memenuhi persyaratan termasuk tempat cuci yang memenuhi syarat dengan air cucian yang mengalir. Peran Dinas Kesehatan sebagai pembina UKS untuk kesehatan terhadap kantin anak, jadi bergerak ke arah kegiatan UKS, terutama bahwa turunnya UKS karena ada kelompok umur yang rawan terhadap masalah kesehatan. Keadaan kesehatan anak sekolah berpengaruh terhadap prestasi belajarnya.

Kegiatan/program pemberdayaan masyarakat pada pengembangan kantin sehat di SMPN 1 Porong dan SMPN 2 Porong untuk pemberdayaan warga sekolah utamanya dalam hal ini jajan makanan anak di sekolah. Program pemberdayaan ini dilaksanakan dengan sasaran pada anak sekolah, kantin dan program dokter kecil. Mengingat bahwa sekolah dan dinas kesehatan memiliki keterbatasan tenaga dan dana maka keterlibatan lintas sektoral sangat diperlukan. Program pemberdayaan dokter anak sekolah sejauh ini belum tepat sasaran pada anak dan pada konteks membangun kompetensi anak dalam mengenal dan mampu memilih jajanan yang sehat dan berguna. Sejauh ini sasaran program masih berada di sekitar anak, yakni pada sekolah, kantin dan PKL. Ketidaktepatan sasaran kegiatan pemberdayaan anak terjadi karena beberapa faktor internal pada anak dan anak mengambil keputusan serta faktor pemberi layanan edukasi kesehatan anak, dalam hal ini adalah instansi pemerintah, sekolah dan lembaga kesehatan. 
Strategi yang digunakan dalam pengembangan kantin sehat di SMPN 1 Porong dan SMPN 2 Porong ini adalah metode ceramah, diskusi, dan pembimbingan (TOT) yang didampingi oleh ahli kesehatan dan atau petugas puskesmas setempat. Kegiatan ini dilakukan sebanyak satu kali di setiap sekolah.

Tahapan selanjutnya yang dilakukan adalah pendampingan manajemen operasional kantin meliputi kegiatan pendampingan penyusunan dokumen standar manajemen operasional kantin meliputi SOP pengelolaan kantin sehat, SOP dan higienitas dan sanitasi kantin, SOP Pelayanan dan tata krama konsumen dan produsen kantin di sekolah dan simulasi cara penyajian jajanan makanan yang sehat, higienis dabn bergizi.

Selanjutnya juga dilakukan pendampingan kegiatan monitoring dan evaluasi pelaksanaan manajemen operasional kantin, serta pendampingan pengujian PJAS dari pencemaran biologis dan kimia ke laboratorium. Kegiatan pendampingan siswa untuk mengembangkan perilaku makan sehat dilakukan dengan membentuk tim kampanye tata krama makan dan pola hidup sehat oleh sekelompok siswa OSIS yang dikoordinir oleh Waka kesiswaan dan guru BK, mengajak siswa membuat poster tentang tata krama atau adab makan dan pentingnya mengkonsumsi pangan sehat, serta mengajak siswa menilai diri sendiri atas jajanan makanan yang mereka konsumsi selama ini dan menilai pelayanan kantin dengan mengisi buku monitoring.

Pentingnya pemberdayaan melalui pengembangan kantin sehat sekolah bagi siswa-siswinya mendorong untuk dikajinya kembali keberadaan kantin sesuai dengan pedoman-pedoman kebijakan pemerintah yang telah disusun mengenai penyelenggaraan kesehatan lingkungan, sanitasi, dan keamanan pangan di lingkungan sekolah. Penelitian ini dilakukan di SMPN 1 Porong dan SMPN 2 Porong yang menerapkan kantin sehat dengan merujuk pada kesesuaian kantin sekolah dengan Pedoman Keputusan Menteri Kesehatan No 1429 tahun 2006; Keputusan Menteri Kesehatan Republik Indonesia No.942/Menkes/SK/VII/2003; Pedoman Kementerian Kesehatan Republik Indonesia tahun 2011 mengenai Keamanan Pangan di Sekolah dasar; dan Pedoman Keamanan di Kantin Sekolah dari Badan Pengawas Obat dan Makanan (BPOM) tahun 2012.

\section{Peran Kelembagaan bagi Pengembangan Kantin Sekolah}

Peran kelembagaan, yakni dinas kesehatan kota dan dinas pendidikan menjadi penting, karena setiap lembaga mempunyai rencana strategis, yang didalamnya meliputi analisis lingkungan baik eksternal maupun internal, misi, tujuan, strategi dan kebijakan yang akan dicapai. Di samping aspek kelembagaan, faktor lain yang berperan dalam pembinaan terkait denagn jajan makanan anak di sekolah, antara lain: 


\section{Murid/siswa}

Bila siswa dalam memilih makanan jajanan benar dan sehat, maka akan terlindung dari penyakit. Hal sebaliknya, jika tidak benar memilih makanan jajanan, maka akan sudah terserang penyakit. Direktorat Bina Kesehatan Anak mempunyai agenda untuk meningkatkan peran peserta didik dalam program UKS melalui kegiatan penyampaian informasi kepada siswa tentang gizi seimbang, makanan sehat dan bersih. Siswa sebagai sasaran langsung, diharapkan kegiatan tersebut mampu meningkatkan pemahaman anak terhadap pangan sehat. Pembinaan PJAS di sekolah selama ini belum ada dasarnya, sehingga kegiatan ini tidak dilakukan, hanya menunggu dari sektor lain yang melakukan kegiatan tersebut. Orangtua memiliki peran langsung dalam membentuk pengetahuan anak mengenai nutrisi makanan jajanan. Karena itulah, komunikasi orangtua dalam keluarga terkait dengan pemahaman nutrisi menjadi penting.

Penumbuhkembangan perilaku hidup sehat pada siswa melibatkan peran personil sekolah yang meliputi peran kepala sekolah sebagai leader dalam menciptakan suasana lingkungan kerja kondusif dan melibatkan semua elemen yang ada di sekolah dalam mengambil keputusan terkait kebijakan sekolah dengan bermusyawarah, kepala sekolah sebagai inovator yang memiliki inovasi dengan menggagas program sekolah tentang perilaku hidup sehat, kepala sekolah berperan sebagai motivator dalam memberikan motivasi kepada guru dan siswa dengan memberikan penghargaan pada siswa apabila siswa berperilaku hidup sehat di sekolah. Peran guru sebagai pembimbing siswa dalam perilaku hidup sehat di sekolah dengan memberikan arahan dan memberikan contoh tentang berperilaku hidup bersih dan sehat di sekolah, guru sebagai pengelola kelas dengan membuat aturan dan tata tertib yang bertujuan untuk menumbuhkembangkan perilaku hidup sehat.

Strategi yang digunakan dalam proses menumbuhkembangkan perilaku hidup sehat pada siswa di sekolah juga bisa dilakukan melalui pembelajaran di dalam kelas dengan menggunakan kurikulum 2013 yang menyangkut tema kebersihan, kesehatan diri, dan lingkungan. Selain itu, strategi pemberitahuan kepada orangtua mengenai program perilaku hidup sehat di sekolah melalui buku penghubung yang berisi peraturan dan tata tertib sekolah yang harus ditaati oleh seluruh siswa terutama mengenai disiplin dalam kebersihan diri dan kewajiban untuk menjaga kebersihan lingkungan sekolah. Upaya sekolah memberikan reward dan punishment kepada siswa dalam menerapkan perilaku hidup sehat di sekolah adalah dengan memberikan pujian serta penghargaan dan diumumkan pada saat upacara, diadakan lomba kebersihan kelas, dan didalam kelas diberikan predikat sebagai best student on the week. Sementara itu, punishment digunakan di sekolah bagi siswa yang melanggar dengan memberikan teguran berupa nasehat dan teguran secara verbal yang memberitahukan kepada siswa bahwa tindakan tersebut tidak mencerminkan perilaku yang baik serta diberi sanksi untuk membersihkan kelas dan memunggut sampah yang berserakan dan lain sebagainya. 


\section{Penjual makanan jajanan}

Penjual makanan jajanan merupakan salah satu faktor kejadian penyakit pada anak sekolah. Hal ini karena pengetahuan penjual makanan jananan terhadap keamanan pangan masih kurang. Bila penjual makanan dalam menjual makanannya dilakukan dengan cara pengelolaan dan cara penyajiannya dengan baik dan benar, higiene perorangan mereka baik, dan kualitas makanan jajanan yang dijual baik, maka anak-anak akan terjaga untuk terjadinya kejadian penyakit. Satu contoh makanan basah tanpa kemasan yang tidak menggunakan pembungkus dari bahan plastik di kantin SMPN 2 Porong adalah makanan yang digoreng berupa risoles, pisang madu, dan bakso tusuk. Makanan basah ini tidak ditaruh

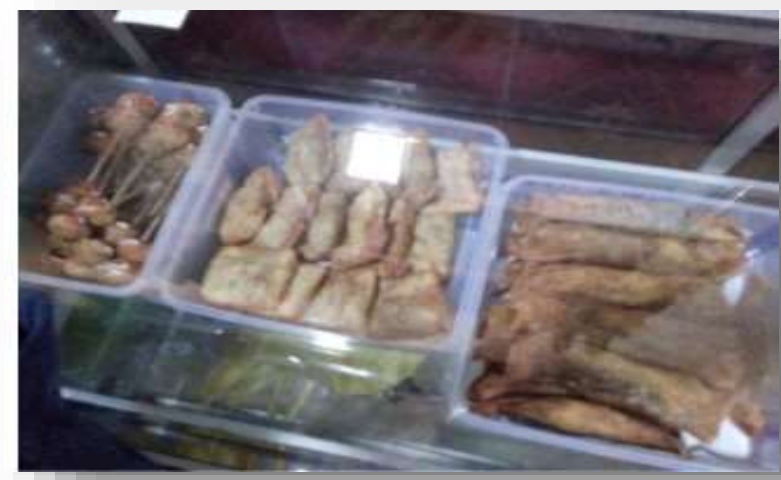

Gambar 2.2 Kemasan makanan basah dalam kemasan tersendiri tetapi hanya diletakkan di nampan dan etalase saja.

Demikian juga beberapa contoh jenis jajan makanan yang ada di SMPN 1 Porong seperti pada gambar 2.3 yang tidak menyediakan alat makan sehingga tingkat higienis makanan kurang layak ketika siswa harus makan tidak ada alat makan yang sesuai.

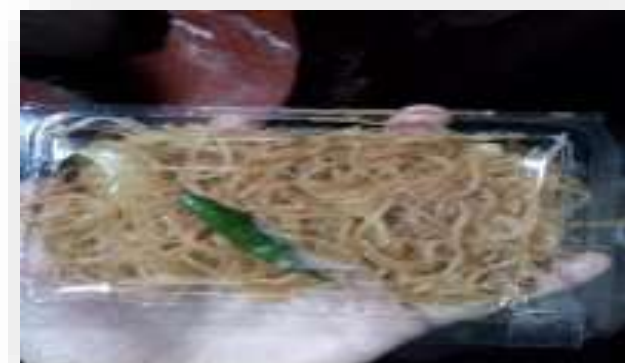

Gambar 2.3 Kemasan tanpa sendok makan

\section{Guru/Kepala Sekolah}

Guru/kepala sekolah yang membina usaha kesehatan sekolah (UKS) merupakan salah faktor yang sangat menentukan terjaganya kualitas makanan jajanan sehat di sekolahnya. Hal ini menjadi peran kepala sekolah atau guru UKS dalam membina anakanak untuk membiasakan makanan jajanan yang sehat dan bersih. Selain itu, harus melakukan pembinaan terhadap para penjual agar menjual makanannya dalam kondisi bersih dan sehat.

\section{Pengembangan Kantin Sehat Sekolah}

Kantin sehat diadakan karena keprihatinan atas banyaknya jajanan sekolah yang mengandung zat aditif sehingga berbahaya bagi kesehatan. Selain itu kantin sehat juga merupakan implementasi program Adiwiyata melalui pengelolaan sarana pendukung ramah lingkungan dengan peningkatan kualitas pelayanan kantin sehat dan ramah lingkungan. Kantin sehat adalah kantin dengan pengolahan makanan dan sarana 
prasarananya sesuai dengan standar kesehatan. Adanya layanan ini diharapkan dapat memenuhi kebutuhan seluruh warga sekolah untuk mendapat makanan yang higienis dan bergizi. Selain itu, dengan penggunaan sarana prasarana kantin yang ramah lingkungan diharapkan dapat mengatasi permasalahan lingkungan hidup di sekolah.

Syarat-syarat yang diterapkan pada pengembanagan kantin sehat di SMPN 1 Porong dan SMPN 2 Porong nantinya sesuai dengan Keputusan Menteri Kesehatan Republik Indonesia nomor 942/Menkes/SK/VII/2003 tentang Pedoman Persyaratan Hygiene Sanitasi Makanan Jajanan pasal 5 butir 1 yang menyatakan bahwa semua bahan yang diolah menjadi makanan jajanan harus dalam keadaan baik mutunya, segar, dan tidak busuk. Peraturan pemerintah yang dibuat ini seharusnya membatasi mengenai jumlah zat adiktif yang ditambahkan di dalam makanan. Hal ini dikarenakan penggunaan zat adiktif dapat mempengaruhi beberapa kepentingan termasuk perusahan makanan yang akibatnya mudah untuk dimanupulasi.

Pasal 5 butir 2 dalam Keputusan Menteri Kesehatan Republik Indonesia nomor 942/Menkes/SK/VII/2003 tentang Pedoman Persyaratan Hygiene Sanitasi Makanan Jajanan menyatakan bahwa semua bahan olahan dalam kemasan yang diolah menjadi makanan jajanan harus bahan olahan yang terdaftar di Departemen Kesehatan, tidak kadaluwarsa, tidak cacat atau rusak kemasannya. Begitu pula produk makanan yang belum memiliki label izin dari BPOM tidak diperbolehkan untuk dijual di lingkungan sekolah untuk memantau jenis makanan yang aman dikonsumsi siswa.

Menu yang dijual di kantin SMPN 1 Porong dan SMPN 2 Porong SD Negeri dikelompokkan menjadi empat, yaitu 1) makanan berat berupa nasi, mie, dan bihun goreng; 2) makanan ringan/ snack; 3) minuman, seperti teh, juice buah dan sayur, serta susu kemasan, dan 4) jajan pasar, berupa gorengan dan arem-arem. Diantara beberapa menu makanan yang dijual juga cenderung monoton sehingga kurangnya variasi zat gizi yang dikonsumsi. Variasi makanan untuk anak-anak perlu dilakukan untuk meningkatkan konsumsi makanan sehat dan bergizi.

Berikut ini tahapan atau prosedur pemberdayaan pengembangan kantin sehat yang dilakukan di kedua sekolah mitra yakni di SMPN 1 Porong dan SMPN 2 Porong dalam rangka untuk sosialisasi edukatif pentingnya menjaga dan mengkonsumsi jenis jajanan makanan di sekolah secara sehat, aman dan bergizi adalah sebagai berikut.

1. Perencanaan Layanan Kantin Sehat

Perencanaan layanan kantin sehat ini dimulai dengan pembagian tugas guru yang ditunjuk sebagai koordinator dan anggota pelaksana kantin sehat. Pembuatan MOU/Nota kesepakatan bersama antara sekolah dengan penjamah makanan/penjual makanan. Perencanaan pembangunan kantin sehat dan pengadaan sarana prasarana pendukungnya. Penetapan anggaran yang akan digunakan. Perencanaan Layanan Kantin Sehat di SMPN 1 Porong dan SMPN 2 Porong merupakan fungsi pertama yang dilakukan dalam manajemen. Perencanaan ini dilakukan untuk mengatur strategi untuk mencapai 
tujuan yang dinginkan, membuat kebijakan atau peraturan terkait dengan kegiatan yang harus dijalankan. Perencanaan ini penting dilakukan agar dalam pelaksanaan dapat berjalan secara optimal.

Untuk mewujudkan layanan kantin sehat dan ramah lingkungan di SMPN 1 Porong dan SMPN 2 Porong, perencanaan dimulai dengan pembagian tugas. Melalui rapat, kepala sekolah menunjuk guru sebagai koordinator dan anggota pelaksana kantin sehat, membuat nota kesepakatan bersama antar sekolah dengan penjamah/penjual makanan, merencanakan pembangunan kantin dan pengadaan sarana dan pendukungnya serta membuat rancangan anggaran yang dibutuhkan. Dalam perencanaan tersebut standar kesehatan diimplementasikan dalam perencanaan pembangunan kantin dan pengadaan sarana prasarana pendukungnya serta kebijakan dan peraturan yang dimuat dalam nota kesepakatan bersama antara sekolah dan penjamah makanan.

Pelaksanaan program
layanan kantin meningkatkan kualitas layanan kantin sehat dan ramah lingkungan di sekolah. Kegiatan tersebut meliputi menyediakan makanan dan minuman sehat dan menyediakan sarana dan prasarana kantin sesuai dengan standar kesehatan dan ramah lingkungan. Sesuai dengan

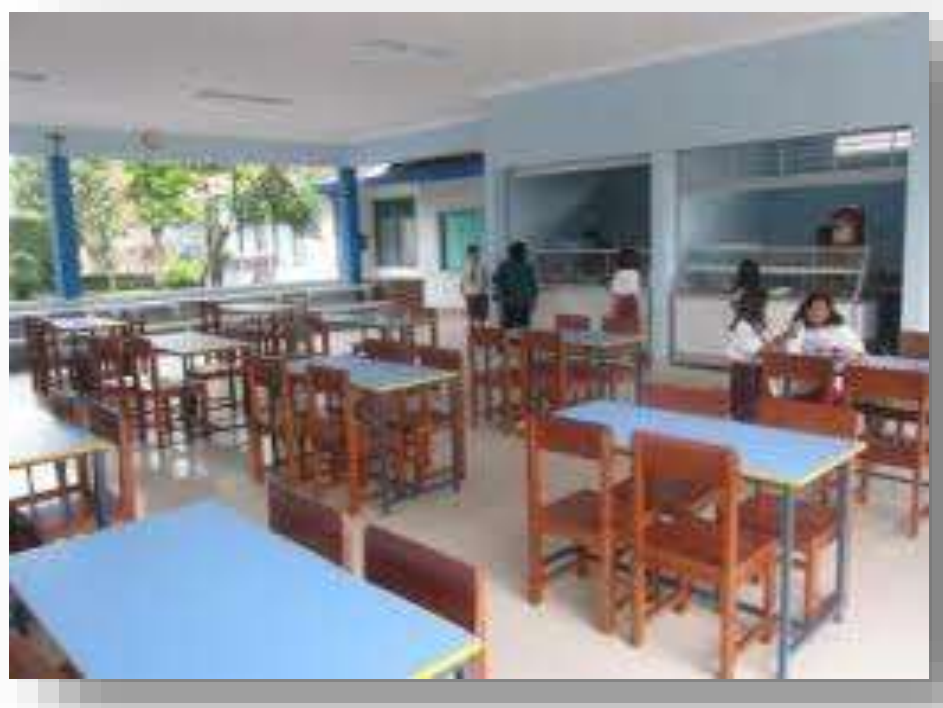

Gambar 2.4. SOP Kantin Sekolah

kebijakan sekolah yang juga dimuat dalam Nota kesepakatan bersama antara sekolah dan penjamah makanan, semua makanan dan minuman yang dijual kantin di SMPN 1 Porong dan SMPN 2 Porong bebas dari 5P (Pemanis, pewarna, perasa, pengenyal dan pengawet). Selain bebas 5P, semua makanan dan minuman yang ada kantin sehat di SMPN 1 Porong dan SMPN 2 Porong diolah oleh penjamah makanan yang telah mengikuti pelatihan dari Dinas Kesehatan Kecamatan Porong Kabupaten Sidoarjo dan atau telah memperoleh sertifikat kursus penjamah makanan dari petugas kesehatan. Sehingga semua penjamah makanan telah memiliki pengetahuan dan pemahaman dalam pengolahan makanan.

Pentingya kantin sehat di sekolah adalah sebagai suatu usaha (tempat) yang dilakukan sekolah untuk memberikan pelayanan terbaik kepada para siswa atau unsur sekolah lainnya yang membutuhkan makanan atau minuman sehat sehingga kegiatan belajar mengajar di sekolah dapat mencapai tujuan secara maksimal. Semua makanan dan minuman yang ada di kantin sehat SMPN 1 Porong dan SMPN 2 Porong dikelola dengan higienis dan sesuai dengan standar operasional prosedur. Penyajian makanan 


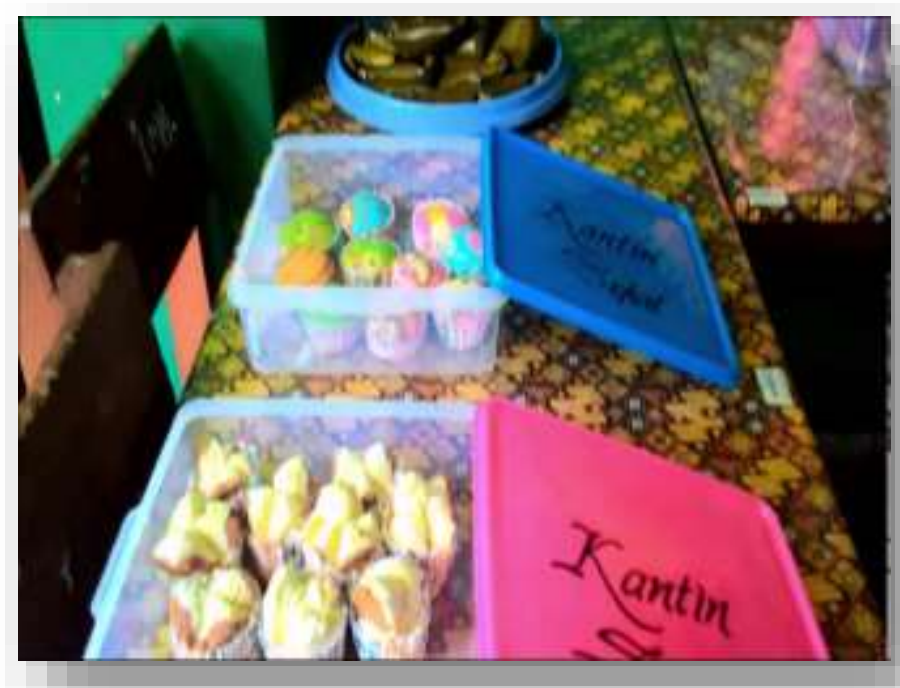

tidak boleh terkena tangan secara langsung sehingga harus menggunakan sarung plastik, penjepit makanan/sendok.

Tempat/wadah/pembungkus tidak terbuat dari bahan plastik, melamine, styrofoam, dan atau alumunium foil. Makanan atau minuman yang sudah disajikan disimpan dalam wadah terutup (untuk kue)/etalase (untuk makanan dan minuman) agar terhindar debu, lalat dan kotoran lainnya. Selain itu pencucian peralatan masak dan peralatan makana dicuci dengan sabun cair dan harus dibilas dengan air yang mengalir.

Kantin terdiri dari stan-stan yang memiliki ruang penyajian dengan etalase sebagai displaymakanan dan ruang pencucian peralatan lengkap dengan keran air, sabun cair serta rak pengering. Selain itu ada tempat makan dengan meja dan kursi yang memadai dan juga washtafel untuk cuci tangan lengkap dengan sabun cair dangan lap bersih. Berbeda dengan kantin makanan kantin kue hanya ada meja yang digunakan sebagai display kue. Selain itu kantin sekolah juga menyediakan fasilitas pembuangan sampah yang sesuai dengan pedoman Keputusan Menteri Kesehatan Nomor 1429 tahun 2006 mengenai penyelenggaraan kesehatan lingkungan sekolah: Syarat-syarat kesehatan kantin sekolah yaitu: (1) tersedia tempat cuci peralatan makan dan minum dengan air yang mengalir, (2) tersedia tempat cuci tangan bagi pengunjung kantin/warung sekolah, (3) tersedia tempat untuk penyimpanan bahan makanan, (4) tersedia tempat menyimpan peralatan makan dan minum, dan lokasi kantin/warung sekolah minimal berjarak 20 meter dengan TPS (tempat pengumpulan sampah sementara). 


\section{Pelaksanaan Layanan Kantin Sehat}

Pelaksanaan layanan kantin sehat di sekolah meliputi beberapa kegiatan yaitu: penempatan lokasi kantin yang memenuhi syarat kebersihan, pemeriksaan berkala terhadap kualitas makanan kantin, kegiatan penyuluhan mengenai pola makan sehat, pengunaan kemasan yang ramah lingkungan, dan juga penyediaan sarana seperti tempat sampah,tempat pencucian, dan saluran pembuangan. Sanitasi kantin sekolah meliputi sanitasi penyajian makanan, dan sanitasi peralatan, diantaranya: 1) telah memiliki fasilitas air bersih yang memenuhi syarat, 2) terdapat sanitasi tempat sampah dan tempat pencucian peralatan di kantin sekolah, dan 3) pembuangan air limbah sesuai Kepmenkes No. 1098/MENKES/SK/VII/2003 tentang Persyaratan Higiene Sanitasi Rumah Makan dan Restoran adalah bahan kedap air, tidak merupakan sumber pencemaran misalnya dengan menggunakan saluran tertutup, septic tank, dan sebagainya.

Tempat sampah seharusnya dibuat dari bahan kedap air, tidak mudah berkarat,

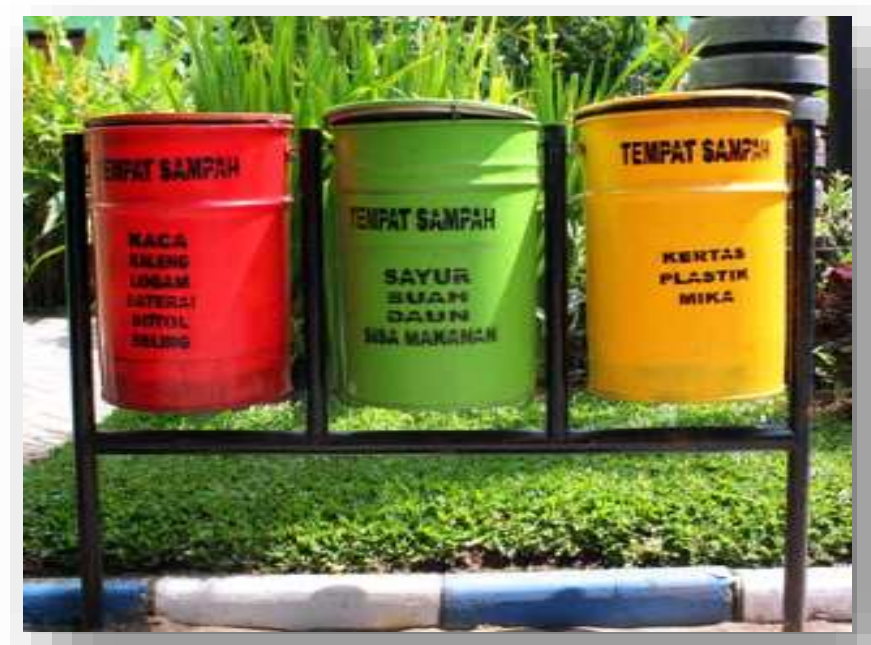

Gambar 2.6. fasilitas pembuangan sampah dan tutup. Hal ini sesuai ketentuan sebagaimana pada Kepmenkes No. 1098/MENKES/ SK/VII/2003 tentang Persyaratan Higiene Sanitasi Rumah Makan dan Restoran, yang menyebutkan bahwa persyaratan tempat pencucian peralatan yaitu terdiri dari 3 bak pencucian yang berguna untuk mengguyur, menyabun dan membilas. Dengan demikian, tempat pencucian peralatan harus memiliki jumlah air yang mencukupi dan tersedia sabun cuci. Tempat penirisan diperlukan untuk mengeringkan peralatan tanpa menggunakan lap/serbet untuk menghindari adanya kontaminasi silang atau kontaminasi ulang pada peralatan yang telah dibersihkan.

Menurut Kepmenkes No. 1098/MENKES/ SK/VII/2003 tentang Persyaratan Higiene Sanitasi Rumah Makan dan Restoran, terdapat beberapa syarat dalam penyajian makanan antara lain: harus terhindar dari pencemaran; peralatan untuk penyajian harus terjaga kebersihannya; harus diwadahi dan dijamah dengan peralatan yang bersih; dan penyajian dilakukan dengan perilaku yang sehat dan pakaian yang bersih. Menurut Purnawijayanti (2001), idealnya proses pencucian peralatan-peralatan pada tempat penyelenggaraan makan melalui beberapa tahapan yaitu pembuangan sisa makanan dan pembilasan awal dengan tujuan agar air dalam bak lebih efisien penggunaannya, bak pertama berisi larutan detergen atau sabun cuci peralatan dengan bantuan spon yang bertujuan membersihkan semua kotoran sisa makanan atau lemak, pembilasan 
dilakukan pada bak kedua dengan menggunakan air hangat untuk menghilangkan sisa detergen atau sabun cuci peralatan. Pada selanjutnya dibilas dengan air disinfektan, namun hal tersebut belum umum dilakukan oleh penjual pada tingkat kantin sekolah. Setelah dicuci, peralatan ditiriskan dan dikeringkan tanpa menggunakan lap atau serbet. Perendaman dilakukan untuk menghilangkan sisa makanan yang menempel pada peralatan makanan sehingga mudah untuk dibersihkan.

Distribusi sanitasi penyajian makanan pada kantin SMPN 1 Porong dan SMPN 2 Porong meliputi kebersihan meja penyajian, cara menyajikan dan mengambil makanan serta batas maksimal peralatan dicuci yang telah memenuhi syarat. Kepmenkes No. 1098/MENKES/SK/ VII/2003 tentang Persyaratan Higiene Sanitasi Rumah Makan dan Restoran menyebutkan bahwa penyajian makanan harus memenuhi beberapa persyaratan termasuk didalamnya yaitu meja penyajian harus tertutup kain putih atau tutup plastik berwarna menarik kecuali bila meja dibuat dari formica, taplak tidak mutlak ada.

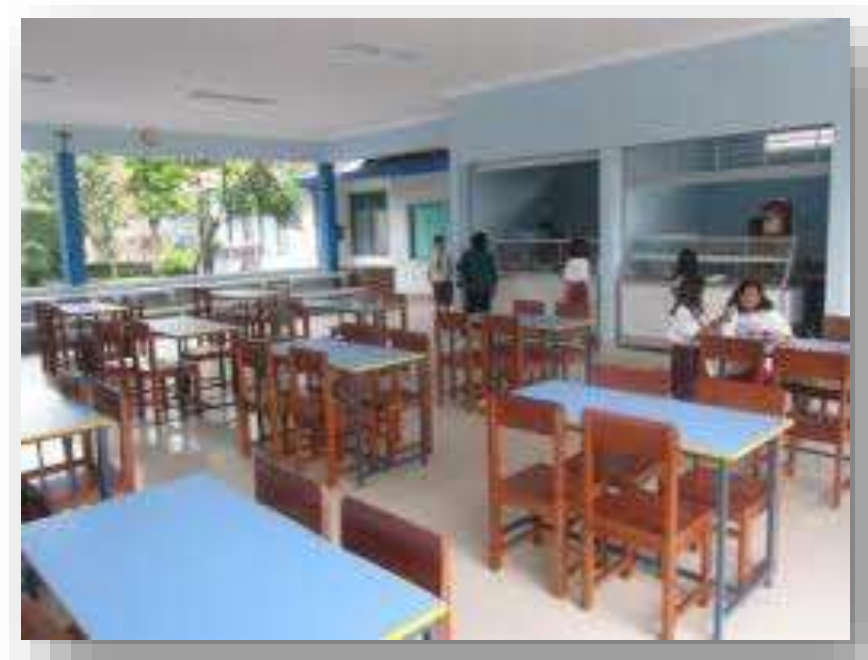

Gambar 2.7. kebersihan meja penyajian

Variasi menu yang disajikan dan juga bergizi mengatur dan menyusun menu supaya menu yang disajikan memiliki gizi seimbang. Semua makanan dan minuman yang ada di kantin sehat dalam pengawasan tim monitoring kantin sehat untuk memastikan agar makanan dan minuman diolah dan disajikan sesuai dengan yang disepakati bersama sehingga makanan tersebut aman, sehat dan bergizi. Makanan dan minuman yang disajikan tidak mengandung pengawet, pewarna, pengenyal, perasa, dan pemanis. Makanan dan minuman, diolah, dan disajikan dengan higienis karena semua penjamah makanan diwajibkan mengunakan perlengkapan saat pengolahan dan penyajian, seperti: celemek, penutup kepala, dan peralatan lain seperti sarung tangan, sendok ataupun penjepit makanan, selain itu makanan/minuman tersebut disimpan di lemari kaca/etalase tertutup untuk mengindari debu ataupun lalat. Semua peralatan masak dan peralatan makan dicuci dengan air bersih menggunakan sabun cair dan harus dibilas dengan air yang mengalir. Tempat/wadah/pembungkus tidak terbuat dari bahan plastik, melamine, styrofoam, dan atau aluminium foil (untuk makanan dan minuman menggunakan mangkuk/piring keramik serta gelas dari kaca, dengan sendok/garpu stainlees, sedangkan untuk kue menggunakan daun sebagai alas atau pembungkus). 


\section{Sarana dan Prasarana Kantin Sekolah}

Kantin makanan terdiri dari stan-stan yang memiliki ruang penyajian dengan etalase sebagai display makanan dan ruang pencucian peralatan lengkap dengan keran air, sabun cair serta rak pengering. Selain itu ada tempat makan dengan meja dan kursi yang memadai dan juga washtafel untuk cuci tangan lengkap dengan sabun cair dangan lap bersih. Kantin kue juga memiliki dua pintu dan jendela kaca yang digunakan sebagai ventilasi dan juga sumber cahaya alami sehingga hemat energi. Berbeda dengan kantin makanan, kantin kue hanya ada meja yang digunakan sebagai displaykue. Selain itu kantin kue juga memimiliki tempat pencucian peralatan yang berada di luar kantin. Taman kantin terlihat bersih, rindang dan nyaman dengan paving blok, pohon-pohon tanaman dalam pot dan juga kolam ikan. Pada taman kantin juga tersedia tempat duduk yang bisa digunakan sebagai tempat makan. Selain itu juga ada fasilitas pembuangan limbah dan sumur resapan.
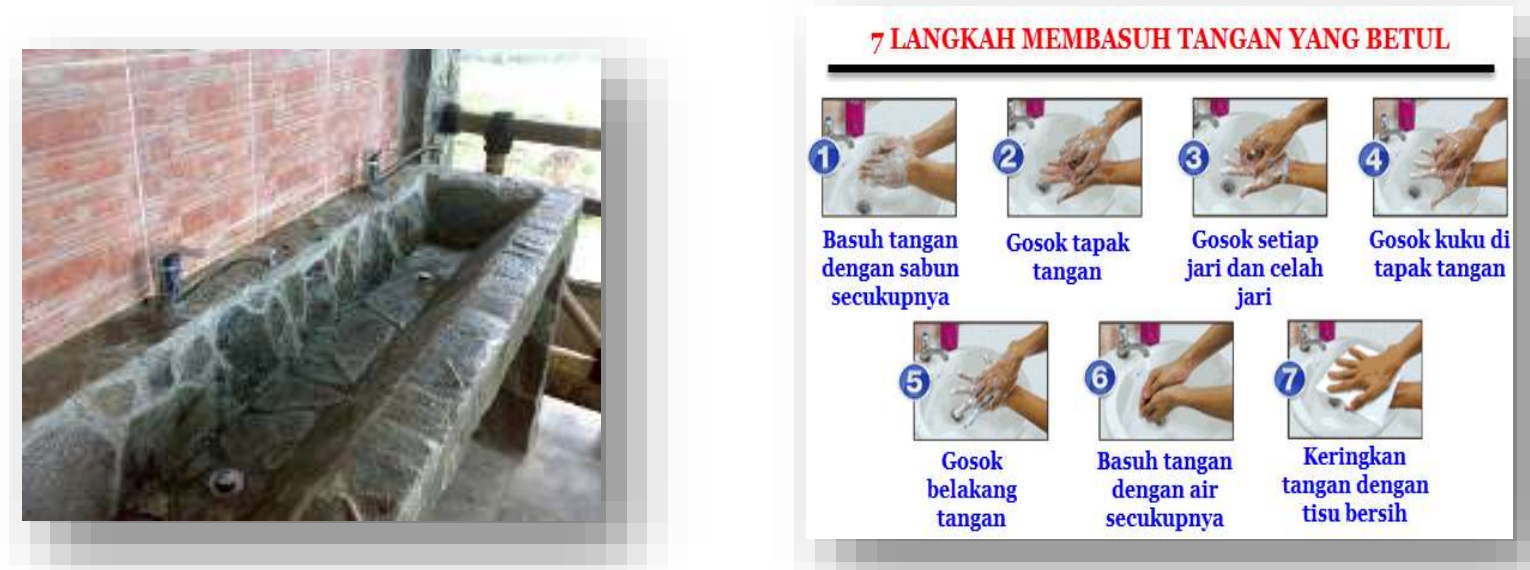

Gambar 2.8. washtafel \& tutorial cuci tangan

\section{Pengawasan Layanan Kantin Sehat}

Pengawasan internal sekolah dilakukan setiap hari oleh petugas bagian monitoring kantin sehat. Pengawasan eksternal dilakukan secara berkala dari petugas dinas kesehatan/puskesmas. Dampak LayananKantin Sehat Pada pelaksanaan suatu program pasti memiliki dampak, begitu juga dengan pelaksanaan layanan kantin sehat di SMPN 1 Porong dan SMPN 2 Porong. Kantin bukan semata-mata mengejar keuntungan saja, akan tetapi ada proses pembelajaran yang dapat diambil dari pelaksanaan layanan kantin tersebut.Dampak dari layanan kantin sehat, yaitu terpenuhinya kebutuhan untuk mendapatkan makanan dan minuman yang higieniz dan bergizi di sekolah, membangun karakter peserta didik untuk bisa memilih makanan yang baik, terwujudnya lingkungan sekolah yang bersih, sehat, nyaman dan ramah lingkungan.

Sekolah merupakan tempat yang efektif bagi pembelajaran dan penyadaran warga sekolah sebagai upaya penanaman rasa cinta lingkungan. Adanya program sekolah peduli dan berbudaya lingkungan memberikan perubahan budaya sekolah dan perilaku warga sekolah menjadi berwawasan lingkungan dengan memasukkan nilai-nilai lingkungan ke 
dalam aktifitas/pengelolaan sekolah. Tujuan diadakannya layanan kantin sehat ini adalah untuk meningkatkan derajat kesehatan seluruh warga sekolah, khususnya peserta didik. Adanya layanan ini diharapkan dapat memenuhi kebutuhan seluruh warga sekolah untuk mendapatkan makanan yang higienis dan bergizi sehingga dengan kondisi fisik yang sehat diharapkan pula agar peserta didik menjadi energik, kreatif, dan dapat mengikuti kegiatan belajar dengan baik serta prestasi belajar meningkat.

Pengawasan layanan kantin sehat ini dilakukan untuk memonitoring pelaksanaan layanan kantin sehat agar sesuai dengan tujuan dan rencana yang telah ditetapkan sebelumnya. Hasil pengawasan ini dapat dijadikan tolak ukur bagi kepala sekolah maupun pengurus kantin untuk menjaga dan meningkatkan kualitas layanan kantin. Pengawasan internal dilakukan setiap hari oleh petugas bagian monitoring. Sedangkan pengawasan eksternal dilakukan secara berkala oleh petugas puskesmas. Pengawasan adalah proses pengamatan dan pengukuran suatu kegiatan operasional dan hasil yang dicapai dibandingkan dengan standar yang telah ditetapkan sebelumnya dalam perencanaan.

\section{Upaya Perbaikan Kantin Sehat}

Untuk mengurangi paparan anak sekolah terhadap makanan jajanan yang tidak sehat dan tidak aman, perlu dilakukan usaha promosi keamanan pangan baik kepada pihak sekolah, guru, orang tua, murid, serta pedagang. Sekolah dan pemerintah perlu menggiatkan kembali UKS (Usaha Kesehatan Sekolah). Materi sosialisasi tentang keamanan pangan yang sudah pernah dilakukan oleh Badan POM dan Departemen Kesehatan dapat ditingkatkan penggunaannya sebagai alat bantu penyuluhan keamanan pangan di sekolah-sekolah. Perlu diupayakan pemberian makanan ringan atau makan siang yang dilakukan di lingkungan sekolah. Hal ini dilakukan untuk mencegah agar anak tidak sembarang jajan.

Koordinasi oleh pihak sekolah, persatuan orang tua murid dibawah konsultasi dokter sekolah atau Pusat Kesehatan Masyarakat yakni Puskesmas setempat untuk dapat menyajikan makanan ringan pada jam istirahat yang bisa diatur porsi dan nilai gizinya. Upaya ini tentunya akan lebih murah dibanding anak jajan diluar sekolah yang tidak ada jaminan gizi dan kebersihannya. Ibu yang selalu khawatir biasa memberi bekal makanan pada anaknya. Kalau makanan yang baik dan bergizi tersedia disekolah, akan meringankan tugas ibu. Dalam kegiatan ini bisa pula dikenalkan berbagai jenis bahan makanan yang mungkin tidak disukai anak ketika disajikan dirumah, tetapi akan menerima ketika disajikan disekolah. Dengan demikan anak dapat mengenal aneka bahan pangan. Minuman yang dianggap tak bermanfaat itu akan diganti dengan air putih, susu dan buah-buahan dan minuman olahraga. Hal ini menunjukkan suatu kepedulian terhadap kesehatan anak usia sekolah. Bahaya yang senantiasa mengancam kesehatan anak usia sekolah karena perilaku makan ini harus diperhatikan oleh semua pihak. Orang 
tua, guru, persatuan orang tua murid dan guru, pemerintah daerah khususnya departemen pendidikan dan departemen kesehatan harus mulai mengambil langkah cepat berkoordinasi untuk melakukan upaya perbaikkan. Perlu dipikirkan pembuatan peraturan atau kebjaksanaan baik oleh pihak sekolah atau instansi terkait sehingga dapat mengatasi masalah ini. Peningkatan perhatian kesehatan anak usia sekolah ini diharapkan dapat mengciptakan peserta didik yang sehat, cerdas dan berprestasi. 


\section{LAMPIRAN}

\section{KEPUTUSAN MENTERI KESEHATAN REPUBLIK INDONESIA}

NOMOR 942/MENKES/SK/VII/2003

\section{TENTANG}

\section{PEDOMAN PERSYARATAN HYGIENE SANITASI MAKANAN JAJANAN \\ MENTERI KESEHATAN REPUBLIK INDONESIA,}

Menimbang: a. bahwa masyarakat perlu dilindungi dari makanan dan minuman yang tidak memenuhi persyaratan kesehatan agar tidak membahayakan kesehatannya;

b. bahwa persyaratan makanan jajanan yang ditetapkan dalam Peraturan Menteri Kesehatan Nomor 236/Menkes/Per/IV/1997 perlu disempurnakan dan ditinjau kembali dalam rangka pelaksanaan Otonomi Daerah;

c. bahwa sehubungan dengan huruf $a$ dan $b$ tersebut perlu ditetapkan Pedoman Persyaratan Hygiene Sanitasi Makanan Jajanan dengan Keputusan Menteri Kesehatan;

Mengingat: 1. Undang-Undang Nomor 4 Tahun 1984 tentang Wabah Penyakit Menular (Lembaran Negara Tahun 1984 Nomor 20, Tambahan Lembaran Negara Nomor 3273);

2. Undang-undang Nomor 23 Tahun 1992 tentang Kesehatan (Lembaran Negara Tahun 1992 Nomor 100, Tambahan Lembaran Negara Nomor 3495);

3. Undang-undang Nomor 7 Tahun 1996 tentang Pangan (Lembaran Negara Tahun 1996 Nomor 99, Tambahan Lembaran Negara Nomor 3656);

4. Undang-Undang Nomor 22 Tahun 1999 tentang Pemerintahan Daerah (Lembaran Negara Tahun 1999 Nomor 60, Tambahan Lembaran Negara Nomor 3839);

5. Undang-Undang Nomor 25 Tahun 1999 tentang Perimbangan Keuangan Antara Pusat dan daerah (Lembaran Negara Tahun 1999 Nomor 72, Tambahan Lembaran Negara Nomor 3848);

6. Peraturan Pemerintah Nomor 40 Tahun 1991 tentang Penanggulangan Wabah Penyakit Menular (Lembaran Negara Tahun 1991 Nomor 49, Tambahan Lembaran Negara Nomor 3447);

7. Peraturan Pemerintah Nomor 25 Tahun 2000 tentang Kewenangan Pemerintah dan Kewenangan Propinsi Sebagai Daerah Otonom (Lembaran Negara Tahun 2000 Nomor 54, Tambahan Lembaran Negara Nomor 3952); 
8. Keputusan Menteri Kesehatan Republik Indonesia Nomor 1277/Menkes/SK/XI/2001 tentang Organisasi dan Tata Kerja Departemen Kesehatan RI;

\section{MEMUTUSKAN : \\ Menetapkan: KEPUTUSAN MENTERI KESEHATAN TENTANG PEDOMAN PERSYARATAN HYGIENE SANITASI MAKANAN JAJANAN.}

\section{BAB I \\ KETENTUAN UMUM \\ Pasal 1}

Dalam keputusan ini yang dimaksud dengan :

1. Makanan jajanan adalah makanan dan minuman yang diolah oleh pengrajin makanan di tempat penjualan dan atau disajikan sebagai makanan siap santap untuk dijual bagi umum selain yang disajikan jasa boga, rumah makan/restoran, dan hotel.

2. Penanganan makanan jajanan adalah kegiatan yang meliputi pengadaan, penerimaan bahan makanan, pencucian, peracikan, pembuatan, pengubahan bentuk, pewadahan, penyimpanan, pengangkutan, penyajian makanan atau minuman.

3. Bahan makanan adalah semua bahan makanan dan minuman baik terolah maupun tidak, termasuk bahan tambahan makanan dan bahan penolong.

4. Hygiene sanitasi adalah upaya untuk mengendalikan faktor makanan, orang, tempat dan perlengkapannya yang dapat atau mungkin dapat menimbulkan penyakit atau gangguan kesehatan.

5. Penjamah makanan jajanan adalah orang yang secara langsung atau tidak langsung berhubungan dengan makanan dan peralatannya sejak dari tahap persiapan,pembersihan, pengolahan, pengangkutan sampai dengan penyajian.

6. Pengelola sentra adalah orang atau badan yang bertanggungjawab untuk mengelola tempat kelompok pedagang makanan jajanan.

7. Peralatan adalah barang yang digunakan untuk penanganan makanan jajanan.

8. Sarana penjaja adalah fasilitas yang digunakan untuk penanganan makanan jajanan baik menetap maupun berpindah-pindah.

9. Sentra pedagang makanan jajanan adalah tempat sekelompok pedagang yang melakukan penanganan makanan jajanan. 


\section{BAB II \\ PENJAMAH MAKANAN \\ Pasal 2}

Penjamah makanan jajanan dalam melakukan kegiatan pelayanan penanganan makanan jajanan harus memenuhi persyaratan antara lain :

a. tidak menderita penyakit mudah menular misal : batuk, pilek, influenza, diare, penyakit perut sejenisnya;

b. menutup luka (pada luka terbuka/ bisul atau luka lainnya);

c. menjaga kebersihan tangan, rambut, kuku, dan pakaian;

d. memakai celemek, dan tutup kepala;

e. mencuci tangan setiap kali hendak menangani makanan.

f. menjamah makanan harus memakai alat/ perlengkapan, atau dengan alas tangan;

g. tidak sambil merokok, menggaruk anggota badan (telinga, hidung, mulut atau bagian lainnya);

h. tidak batuk atau bersin di hadapan makanan jajanan yang disajikan dan atau tanpa menutup mulut atau hidung.

\section{BAB III \\ PERALATAN}

Pasal 3

1) Peralatan yang digunakan untuk mengolah dan menyajikan makanan jajanan harus sesuai dengan peruntukannya dan memenuhi persyaratan hygiene sanitasi.

2) Untuk menjaga peralatan sebagaimana dimaksud pada ayat (1):

a. peralatan yang sudah dipakai dicuci dengan air bersih dan dengan sabun;

b. lalu dikeringkan dengan alat pengering/lap yang bersih

c. kemudian peralatan yang sudah bersih tersebut disimpan di tempat yang bebas pencemaran.

3) Dilarang menggunakan kembali peralatan yang dirancang hanya untuk sekali pakai

\section{BAB IV \\ AIR, BAHAN MAKANAN, BAHAN \\ TAMBAHAN DAN PENYAJIAN}

\section{Pasal 4}

1) Air yang digunakan dalam penanganan makanan jajanan harus air yang memenuhi standar dan Persyaratan Hygiene Sanitasi yang berlaku bagi air bersih atau air minum.

2) Air bersih yang digunakan untuk membuat minuman harus dimasak sampai mendidih. 


\section{Pasal 5}

1) Semua bahan yang diolah menjadi makanan jajanan harus dalam keadaan baik mutunya, segar dan tidak busuk.

2) Semua bahan olahan dalam kemasan yang diolah menjadi makanan jajanan harus bahan olahan yang terdaftar di Departemen Kesehatan, tidak kadaluwarsa, tidak cacat atau tidak rusak.

\section{Pasal 6}

Penggunaan bahan tambahan makanan dan bahan penolong yang digunakan dalam mengolah makanan jajanan harus sesuai dengan ketentuan perundang-undangan yang berlaku.

\section{Pasal 7}

1) Bahan makanan, serta bahan tambahan makanan dan bahan penolong makanan jajanan siap saji harus disimpan secara terpisah

2) Bahan makanan yang cepat rusak atau cepat membusuk harus disimpan dalam wadah terpisah.

\section{Pasal 8}

Makanan jajanan yang disajikan harus dengan tempat/alat perlengkapan yang bersih, dan aman bagi kesehatan.

\section{Pasal 9}

1) Makanan jajanan yang dijajakan harus dalam keadaan terbungkus dan atau tertutup.

2) Pembungkus yang digunakan dan atau tutup makanan jajanan harus dalam keadaan bersih dan tidak mencemari makanan.

3) Pembungkus sebagaimana dimaksud pada ayat (2) dilarang ditiup.

\section{Pasal 10}

1) Makanan jajanan yang diangkut, harus dalam keadaan tertutup atau terbungkus dan dalam wadah yang bersih.

2) Makanan jajanan yang diangkut harus dalam wadah yang terpisah dengan bahan mentah sehinggga terlindung dari pencemaran.

\section{Pasal 11}

Makanan jajanan yang siap disajikan dan telah lebih dari 6 (enam) jam apabila masih dalam keadaan baik, harus diolah kembali sebelum disajikan.

\section{BAB V \\ SARANA PENJAJA}

Pasal 12

1) Makanan jajanan yang dijajakan dengan sarana penjaja konstruksinya harus dibuat sedemikian rupa sehingga dapat melindungi makanan dari pencemaran.

2) Konstruksi sarana penjaja sebagaimana dimaksud pada ayat (1) harus memenuhi persyaratan yaitu antara lain:

b. mudah dibersihkan;

c. tersedia tempat untuk : 
1. air bersih;

2. penyimpanan bahan makanan;

3. penyimpanan makanan jadi/siap disajikan;

4. penyimpanan peralatan;

5. tempat cuci (alat, tangan, bahan makanan);

6. tempat sampah.

3) Pada waktu menjajakan makanan persyaratan sebagaimana dimaksud pada ayat (2) harus dipenuhi, dan harus terlindungi dari debu, dan pencemaran

\section{BAB VI \\ SENTRA PEDAGANG \\ Pasal 13}

1) Untuk meningkatkan mutu dan hygiene sanitasi makanan jajanan, dapat ditetapkan lokasi tertentu sebagai sentra pedagang makanan jajanan.

2) Sentra pedagang makanan jajanan sebagaimana dimaksud pada ayat (1) lokasinya harus cukup jauh dari sumber pencemaran atau dapat menimbulkan pencemaran makanan jajanan seperti pembuangan sampah terbuka, tempat pengolahan limbah, rumah potong hewan, jalan yang ramai dengan arus kecepatan tinggi.

3) Sentra pedagang makanan jajanan harus dilengkapi dengan fasilitas sanitasi meliputi :

a. air bersih;

b. tempat penampungan sampah;

c. saluran pembuangan air limbah;

d. jamban dan peturasan;

e. fasilitas pengendalian lalat dan tikus;

4) Penentuan lokasi sentra pedagang makanan jajanan ditetapkan oleh pemerintah Daerah Kabupaten/Kota.

\section{Pasal 14}

1) Sentra pedagang makanan jajanan dapat diselengggarakan oleh pemerintah atau masyarakat.

2) Sentra pedagang makanan jajanan sebagaimana dimaksud pada ayat (1) harus mempunyai pengelola sentra sebagai penanggung jawab.

3) Pengelola sentra pedagang makanan jajanan berkewajiban :

a. mendaftarkan kelompok pedagang yang melakukan kegiatan di sentra tersebut pada Dinas Kesehatan Kabupaten/kota.

b. memelihara fasilitas sanitasi dan kebersihan umum.

c. melaporkan adanya keracunan atau akibat keracunan secepatnya dan atau selambatlambatnya dalam 24 (dua puluh empat) jam setelah menerima atau mengetahui kejadian tersebut kepada Puskesmas/Dinas Kesehatan Kabupaten/kota. 


\section{BAB VII \\ PEMBINAAN DAN PENGAWASAN \\ Pasal 15}

1) Pembinaan dan pengawasan makanan jajanan dilakukan oleh Dinas Kesehatan Kabupaten/kota.

2) Untuk melakukan pembinaan dan pengawasan sebagaimana dimaksud pada ayat (1) dilakukan pendataan terhadap sentra pedagang makanan jajanan dan sarana penjaja sebagaimana tercantum dalam lampiran I Keputusan ini.

3) Terhadap sentra penjaja makanan jajanan maupun penjaja makanan jajanan dapat diberikan tanda telah terdaftar atau stiker telah didaftar.

\section{Pasal 16}

1) Penjamah makanan berkewajiban memiliki pengetahuan tentang hygiene sanitasi makanan dan gizi serta menjaga kesehatan

2) Pengetahuan mengenai hygiene sanitasi makanan dan gizi serta menjaga kesehatan sebagaimana dimaksud pada ayat (1) diperoleh melalui kursus hygiene sanitasi makanan.

3) Pedoman penyelenggaraan kursus hygiene sanitasi makanan sebagaimana dimaksud pada ayat (2) tercantum dalam lampiran II Keputusan ini.

4)

\section{Pasal 17}

Dalam melaksanakan pembinaan dan pengawasan Dinas Kesehatan Kabupaten/ Kota mengikut sertakan instansi terkait, pihak pengusaha, organisasi, profesi, Asosiasi, Paguyuban dan atau Lembaga swadaya masyarakat.

\section{Pasal 18}

Dinas kesehatan Kabupaten/Kota secara berkala menyampaikan laporan pelaksanaan pembinaan dan pengawasan kepada Pemerintah Daerah Kabupaten/Kota secara berjenjang.

\section{Pasal 19}

Ketentuan pembinaan dan pengawasan makanan jajanan ditetapkan lebih lanjut oleh Pemerintah Daerah Kabupaten/Kota.

\section{BAB VIII \\ KETENTUAN PERALIHAN}

Pasal 20

Semua sentra dan penjaja makanan yang telah melakukan kegiatan sebelum ditetapkannya keputusan ini, harus menyesuaikan dengan keputusan ini dalam waktu selambat lambatnya 2 (dua) tahun. 


\section{BAB IX \\ KETENTUAN PENUTUP \\ Pasal 21}

Dengan ditetapkannya Keputusan Menteri ini, maka Peraturan Menteri Kesehatan RI Nomor 236/Menkes/Per/IV/1997 tentang Persyaratan Kesehatan Makanan Jajanan dinyatakan tidak berlaku lagi.

Pasal 22

Keputusan ini mulai berlaku pada tanggal ditetapkan.

Ditetapkan di Jakarta

pada tanggal3 Juli 2003

MENTERI KESEHATAN,

Dr. ACHMAD SUJUDI 


\section{LAMPIRAN I \\ KEPUTUSAN MENTERI KESEHATAN \\ NOMOR: 942/Menkes/SK/VII/2003 \\ TANGGAL: 3 JULI 2003}

\section{PEMBINAAN DAN PENGAWASAN SANITASI MAKANAN JAJANAN}

\section{A.PEMBINAAN}

\section{Pendataan}

a. Kegiatan pendataan Makanan Jajanan meliputi penyiapan formulir pendataan, surat tugas, jadwal kegiatan, pencatatan, surat edaran tentang pendataan makanan jajanan kepada Camat, Lurah, Pemilik gedung, semua pedagang makanan jajanan, surat permintaan dukungan dari Instansi terkait dan penyerahan surat pendaftaran kepada pedagang.

b. Pendataan ditujukan kepada pedagang Makanan Jajanan perorangan dan sentra makanan jajanan baik di dalam gedung maupun di luar gedung.

c. Laporan pendataan meliputi jumlah pedagang Makanan Jajanan di luar gedung dan di dalam gedung serta jumlah sentra Makanan Jajanan di dalam gedung dan di luar gedung serta penyebaran pedagang makanan jajanan dan penyebaran sentra Makanan Jajanan.

d. Pendataan dilakukan oleh Dinas Kesehatan Kabupaten/Kota dengan menggunakan cara sedemikian rupa sehingga memperoleh laporan pendataan sebagaimana dimaksud dalam butir (c).

e. Pendataan dilakukan pada setiap awal tahun kalender.

\section{Pendaftaran}

a. Sebelum dilakukan pendaftaran perlu diberitahukan secara luas kepada para pedagang Makanan Jajanan, sentra pedagang Makanan Jajanan dan instansi terkait yang ada di wilayah kerjanya masing-masing.

b. Kegiatan penyiapan instrumen pendaftaran Makanan Jajanan meliputi penyiapan formulir pendaftaran (MJI), buku register, kartu status makanan jajanan, buku kesehatan penjamah, sticker tanda terdaftar pedagang makanan jajanan dan plakat tanda terdaftar sentra makanan jajanan.

c. Dinas Kesehatan Kabupaten/Kota menyediakan instrumen pendaftaran yang dimaksud pada butir (b) dengan mengacu kepada pedoman yang sudah ada.

d. Pendaftaran dilakukan oleh pemohon/pedagang makanan jajanan dengan mengisi formulir pendaftaran (MJI) yang tersedia di Dinas Kesehatan Kabupaten/Kota setempat untuk dicatat dalam buku register pendaftaran.

e. Setiap pedagang Makanan Jajanan yang telah terdaftar diberikan ticker tanda terdaftar dan wajib memasang sticker tanda terdaftar pada sarana penjaja makanan jajanan yang dikelolanya.

f. Hasil laporan pendaftaran adalah diperolehnya informasi tentang pedagang makanan jajanan dan sentra makanan jajanan yang meliputi : jenis/nama makanan jajanan dan sentra makanan jajanan, alamat, nama pemilik, nama dan jumlah penjamah, keanggotaan kelompok/assosiasi, sarana dan lokasi di dalam atau di luar gedung.

\section{Penyuluhan dan Kursus}


a. Kegiatan penyuluhan dilakukan oleh petugas kesehatan dan asosiasi bersama kader di masyarakat terhadap para pedagang dan pemilik untuk memotivasi perilaku yang mendukung pelaksanaan pembinaan Makanan Jajanan.

b. Metode penyuluhan dengan cara memotivasi para pedagang makanan jajanan yang melakukan pendaftaran untuk memberdayakan organisasi yang ada dan atau membentuk organisasi bagi yang belum ada sebagai wahana untuk pembinaan makanan jajanan.

c. Dengan bekerjasama kepada pemilik usaha makanan jajanan, assosiasi dan atau pihak penyandang dana atau Bapak Asuh dilakukan kegiatan kursus bagi Pedagang makanan jajanan untuk Memperoleh Sertifikat Kursus Hygiene Sanitasi Makanan.

\section{Pembentukan Sentra Pedagang Makanan Jajanan}

a. Setiap gedung perkantoran/industri/pusat perdagangan/daerah kegiatan pariwisata yang mempunyai kelompok makanan jajanan atau belum berupa kelompok dilakukan penataan untuk menjadi sentra makanan jajanan.

b. Kelompok makanan jajanan pada butir (a) dilakukan pembinaan dengan melengkapi fasilitas dan sarana pedagang makanan jajanan.

c. Pembentukan sentra pedagang makanan jajanan di motivasi oleh Dinas Kesehatan dan Asosiasi yang telah terdaftar di Pemerintah Daerah setempat dengan dukungan kerjasama dari instansi terkait.

d. Sentra Pedagang makanan jajanan yang telah terbentuk dilakukan inspeksi sanitasi oleh Dinas Kesehatan Kabupaten/kota dan Asosiasi yang telah terdaftar di Pemerintah Daerah setempat untuk diusulkan penetapan lokasi kepada Bupati/Walikota.

e. Setiap gedung perkantoran/industri/pusat perdagangan/ pembelanjaan serta daerah kegiatan pariwisata yang akan dibangun, yang membutuhkan jasa pelayanan makanan diwajibkan menyediakan lahan atau tempat untuk sentra pedagang makanan jajanan baik yang ada di dalam gedung maupun di luar gedung.

f. Persyaratan hygiene sanitasi sentra pedagang makanan jajanan harus memenuhi ketentuan yang telah ditetapkan dalam Keputusan Menteri ini.

g. Pengaturan lebih lanjut tentang persyaratan hygiene sanitasi makanan jajanan ditetapkan oleh Dinas Kesehatan Kabupaten/Kota dan Kantor Kesehatan Pelabuhan, antara lain mencakup :

1. air bersih

2. lalat, tikus dan hewan lainnya

3. sampah

4. limbah

5. pemeliharaan kebersihan

6. perilaku hygienis penjamah

7. pemeriksaan kesehatan

8. ventilasi dan pencahayaan

9. penataan lalu lintas pengunjung

10. suhu penyimpanan bahan makanan

h. Setiap sentra makanan jajanan harus memiliki pengelola sentra sebagai penanggung jawab yang mengkoordinir pedagang makanan jajanan yang ada di dalam sentra makanan jajanani.

i. Pengelola sentra makanan jajanan berkewajiban memelihara kebersihan dan sanitasi lingkungan sentra makanan jajanan. 
j. Sentra makanan jajanan dikembangkan berupa percontohan sentra makanan jajanan yang dibina secara intensif untuk ditularkan kepada daerah lain.

\title{
1. PENGAWASAN
}

A. Pengawasan sentra makanan jajanan dilaksanakan dengan inspeksi sanitasi secara berkala dan penerapan HACCP secara bertahap oleh Dinas Kesehatan Kabupaten/Kota setempat.

B. Inspeksi sanitasi dapat dilaksanakan dengan pengujian contoh sample makanan dan spesimen di laboratorium untuk penegasan/konfirmasi yang dilaksanakan sesuai kebutuhan.

C. Contoh makanan dan spesimen yang dimaksud dalam Keputusan ini yaitu contoh makanan, contoh usap alat masak, contoh usap alat makan, contoh air, contoh usap dubur karyawan dan contoh lainnya.

D. Contoh makanan dan spesimen yang dikirim langsung oleh Penanggung jawab Sentra Pedagang makanan jajanan dapat dilayani bila pengambilannya dilakukan sesuai dengan persyaratan pengambilan contoh makanan dan spesimen.

E. Jenis pemeriksaan yang dilakukan oleh laboratorium sesuai dengan permintaan pengirim.

F. Hasil pemeriksaan dikirim kepada pengirim dengan tembusan kepada Dinas Kesehatan setempat untuk keperluan pemantauan/ pengawasan.

G. Biaya pemeriksaan laboratorium untuk pemeriksaan contoh makanan dan spesimen yang dilakukan secara rutin menjadi tanggung jawab pedagang makanan jajanan yang bersangkutan.

H. Biaya pemeriksaan laboratorium untuk pemeriksaan contoh makanan dan spesimen dalam rangka uji petik ditanggung oleh Pusat, Propinsi dan atau Pemerintah daerah.

I. Laporan hasil inspeksi sanitasi dikirim kepada Bupati/Walikota dan tembusan ke Dinas Kesehatan Kabupaten/Kota, Dinas Kesehatan Propinsi dan Direktorat Penyehatan Air dan Sanitasi Ditjen PPM \& PL Depkes RI dengan periode 3 (tiga) bulan sekali, dengan format laporan MJ3.

J. Sentra makanan jajanan yang telah memenuhi syarat dan menerapkan HACCP dapat diberikan penghargaan atas keberhasilannya.

\section{EVALUASI}

1. Terhadap kegiatan pembinaan dan pengawasan dilakukan evaluasi oleh instansi terkait secara berjenjang.

2. Hasil evaluasi dilaporkan kepada Bupati/Walikota dengan tembusan antara lain kepada Dinas Kesehatan Propinsi, Direktorat Penyehatan Air dan Sanitasi Ditjen PPM \& PL Depkes RI, Jakarta, dan Asosiasi yang telah terdaftar di Pemerintah Daerah untuk dijadikan bahan masukan perencanaan, pembinaan dan pengawasan sanitasi makanan jajanan.

\section{MENTERI KESEHATAN,}

\author{
Dr. ACHMAD SUJUDI \\ LAMPIRAN II \\ KEPUTUSAN MENTERI KESEHATAN
}




\section{NOMOR :942/Menkes/SK/VII/2003 \\ TANGGAL :3 Juli 2003}

\section{PEDOMAN PENYELENGGARAAN KURSUS HYGIENE SANITASI MAKANAN}

A. Peserta, Penyelenggara, Penanggung Jawab dan Pembina Teknis

1. Peserta pelatihan adalah setiap orang dan atau Pengusaha/Penanggung jawab dan penjamah makanan yang yang menangani makanan jajanan.

2. Penyelenggara pelatihan adalah Pusat, Dinas Kesehatan Propinsi, Dinas Kesehatan Kabupaten/Kota atau Lembaga yang telah terdaftar di Pemerintah Daerah setempat.

3. Penanggung jawab pelatihan adalah Ketua Penyelenggara Pelatihan.

4. Pembina teknis pelatihan adalah Direktur Penyehatan Air dan Sanitasi untuk Tingkat Pusat dan Kepala Dinas Kesehatan sesuai dengan tingkat daerahnya.

B. Kurikulum, Materi dan Pengajar atau Tutor

1. Kurikulum pelatihan Hygiene Sanitasi Makanan bagi pengsaha/penanggung jawab dan penjamah makanan sebagaimana tercantum di bawah ini.

2. Materi pelatihan mengacu kepada modul pelatihan yang diterbitkan oleh Departemen Kesehatan.

3. Pengajar atau tutor pelatihan kursus hygiene sanitasi makanan dengan kualifikasi sebagai berikut :

? memiliki pengetahuan hygiene sanitasi makanan yang bersertifikat.

? tenaga Profesi, Sanitarian.

? berpengalaman bekerja dalam bidang terkait.

? berpendidikan minimal S1 (Sarjana).

C. Tutorial dan Evaluasi

1. Peserta pelatihan yang belajar mandiri dapat dibantu dengan tutorial yang dilakukan di Daerah tempat tinggal peserta bekerja, ataupun tempat lain yang ditunjuk oleh penyelenggara pelatihan.

2. Peserta yang memenuhi syarat dalam pelatihan dapat mengikuti evaluasi kursus Hygiene Sanitasi Makanan yang dilaksanakan secara tertulis.

3. Pelaksanaan evaluasi oleh Tim yang dibentuk oleh Penyelenggara Pelatihan.

4. Ketua Tim evaluasi adalah Tenaga Sanitarian yang ditunjuk oleh Ketua Penyelenggara Pelatihan.

5. Tugas tim evaluasi adalah menyusun soal, mengawasi, memeriksa dan menyampaikan hasil evaluasi kepada ketua tim evaluasi.

6. Ketua Tim evaluasi menetapkan peserta yang lulus dalam evaluasi.

D. Sertifikat 
1. Peserta pelatihan yang dinyatakan lulus diberikan sertifikat.

2. Sertifikat dikeluarkan dan ditandatangani oleh Ketua Penyelenggara pelatihan.

3. Sertifikat kursus Hygiene Sanitasi Makanan berlaku secara nasional.

4. Sertifikat kursus Hygiene Sanitasi Makanan berlaku untuk jangka waktu tak terbatas.

5. Bentuk sertifikat kursus Hygiene Sanitasi Makanan dibuat sesuai dengan ketentuan sebagaimana pada contoh pada huruf $\mathrm{G}$ dan $\mathrm{H}$.

\section{E. KURIKULUM KURSUS HYGIENE SANITASI MAKANAN BAGI PENANGGUNGJAWAB MAKANAN}

\begin{tabular}{|c|c|c|c|c|}
\hline Bagian & No & Mata Pelajaran & Pokok Bahasan & $\begin{array}{c}\text { Jam } \\
\text { Pelajaran }\end{array}$ \\
\hline 1 & 2 & 3 & 4 & 5 \\
\hline \multirow[t]{2}{*}{ A. Materi Dasar } & $\mathbf{1}$ & $\begin{array}{l}\text { Peraturan Perundang } \\
\text {-undangan Hygiene } \\
\text { sanitasi Makanan }\end{array}$ & $\begin{array}{l}\text { a.UU No. } 23 / 1992 \\
\text { tentang Kesehatan } \\
\text { b. Perundang-undangan } \\
\text { dibidang Pangan }\end{array}$ & $2 \times 45^{\prime}$ \\
\hline & 2 & $\begin{array}{l}\text { Persyaratan } \\
\text { hygiene sanitasi } \\
\text { Tempat } \\
\text { Pengelolaan } \\
\text { Makanan (TPM) }\end{array}$ & $\begin{array}{l}\text { a. Kepmenkes No } \\
\text {.../2002 Tentang } \\
\text { Persyaratan hygiene } \\
\text { sanitasi makanan } \\
\text { jajanan }\end{array}$ & $2 \times 45^{\prime}$ \\
\hline \multirow[t]{3}{*}{$\begin{array}{l}\text { B. Bahan } \\
\text { Pencemaran } \\
\text { Makanan }\end{array}$} & 3 & $\begin{array}{l}\text { Bahan Pencemar } \\
\text { Terhadap } \\
\text { Makanan }\end{array}$ & $\begin{array}{l}\text { a. Rantai perjalanan } \\
\text { makanan (Food } \\
\text { Chain) } \\
\text { b. Perkembangan } \\
\text { Bakteri Pada } \\
\text { Makanan } \\
\text { c. Dosis Bakteri } \\
\text { Pathogen } \\
\text { d. Cara } \\
\text { Bakteri } \\
\text { Menyebabkan } \\
\text { Penyakit }\end{array}$ & $1 \times 45^{\prime}$ \\
\hline & 4 & $\begin{array}{l}\text { Bahan Pencemar } \\
\text { Makanan Lainnya }\end{array}$ & $\begin{array}{l}\text { a. Virus } \\
\text { b. Zat Asing \& Bahan } \\
\text { Fisik } \\
\text { c. Bahan Kimia }\end{array}$ & $1 \times 45^{\prime}$ \\
\hline & 5 & $\begin{array}{l}\text { Penyakit Bawaan } \\
\text { Makanan }\end{array}$ & $\begin{array}{l}\text { a. Penyebab Oleh } \\
\text { Mikroba } \\
\text { b. Penyebab Oleh } \\
\text { Bahan Kimia } \\
\text { c. Penyebab Oleh Zat } \\
\text { Toksin } \\
\text { d. Penyebab Oleh Zat } \\
\text { Alergi }\end{array}$ & $2 \times 45^{\prime}$ \\
\hline
\end{tabular}




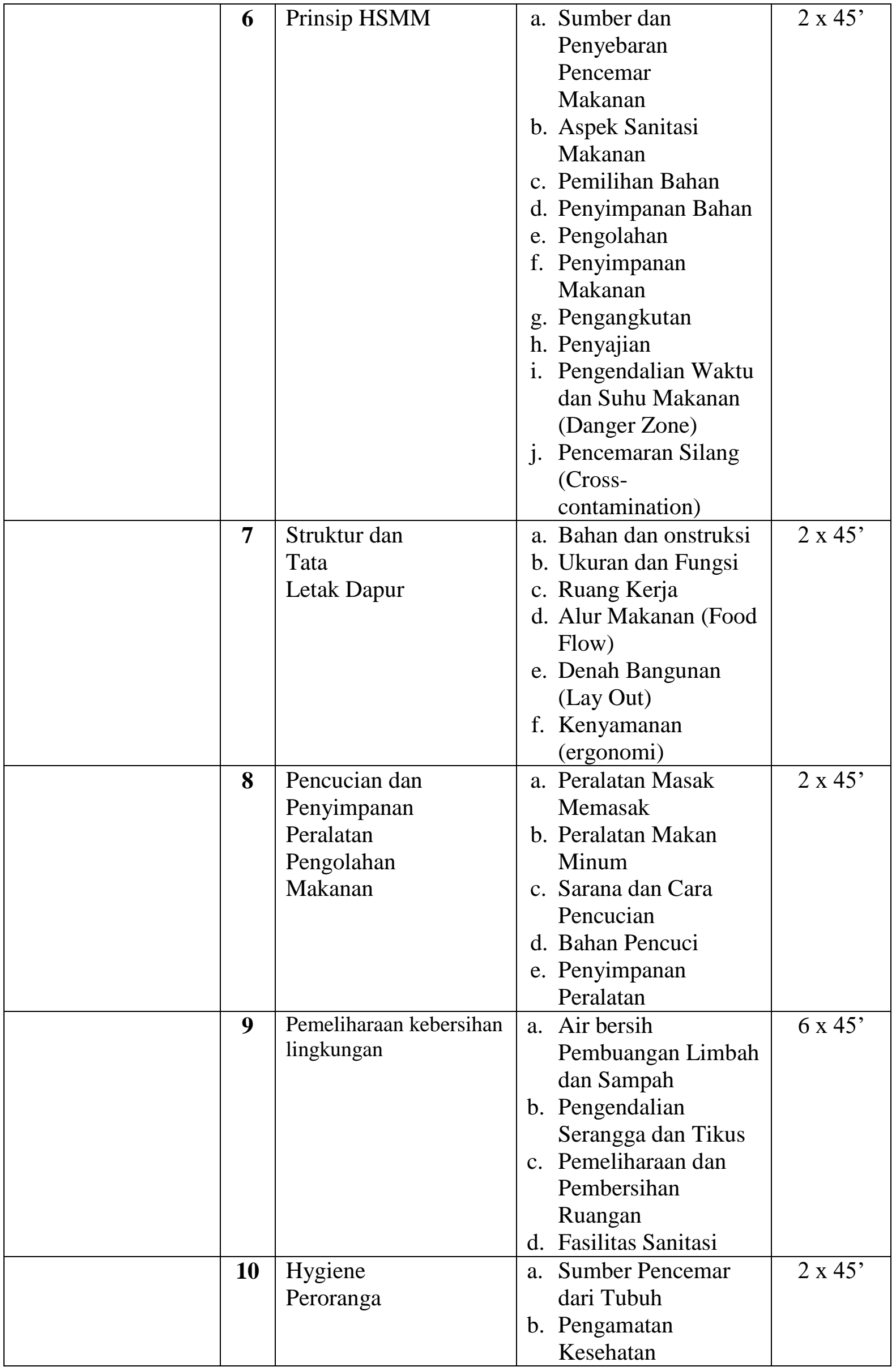




\begin{tabular}{|c|c|c|c|c|}
\hline & & & $\begin{array}{l}\text { c. Pengetahuan, Sikap } \\
\text { dan Perilaku Sehat } \\
\text { d. Pakaian Pelindung } \\
\text { Pencemaran }\end{array}$ & \\
\hline & 11 & $\begin{array}{l}\text { Penanganan Alat } \\
\text { Pendingin }\end{array}$ & $\begin{array}{l}\text { a. Sistem Pendinginan } \\
\text { b. Karakteristik Alat } \\
\text { Pendingin } \\
\text { c. Pelunakan Makanan } \\
\text { d. Beku (Thawing). } \\
\text { e. Pengawasan dan } \\
\text { Pemeliharaan }\end{array}$ & $2 \times 45^{\prime}$ \\
\hline & 12 & $\begin{array}{l}\text { Proses Masak } \\
\text { Memasak } \\
\text { Makanan }\end{array}$ & $\begin{array}{l}\text { a. Cara Memasak Yang } \\
\text { Sehat } \\
\text { b. Hubungan Suhu dan } \\
\text { c. Pemusnahan Bakteri } \\
\text { d. Pemanasan Ulang } \\
\text { (Reheating) }\end{array}$ & $2 \times 45^{\prime}$ \\
\hline & 13 & $\begin{array}{l}\text { Pengawetan dan } \\
\text { Bahan Tambahan } \\
\text { Makanan }\end{array}$ & $\begin{array}{l}\text { a. Pemanasan, } \\
\text { Pengeringan dan } \\
\text { Pengasapan } \\
\text { b. Pengalengan dan } \\
\text { Hampa Udara } \\
\text { c. Penggunaan Bahan } \\
\text { d. Kimia dan Radiasi } \\
\text { e. Bahan Tambahan } \\
\text { Makanan } \\
\text { f. (BTM) }\end{array}$ & $2 \times 45^{\prime}$ \\
\hline & 14 & $\begin{array}{l}\text { Pengendalian } \\
\text { Mutu Mandiri }\end{array}$ & $\begin{array}{l}\text { a. Pengendalian Mutu } \\
\text { (Quality Control) } \\
\text { b. Jaminan Mutu ( } \\
\text { Quality Assurance) } \\
\text { c. Pengujian Mandiri ( } \\
\text { Self Control) } \\
\text { d. Analisis Bahaya } \\
\text { Titik Kendali Kritis } \\
\text { (ABTKK) } \\
\text { e. Hazard Analysis } \\
\text { Critical Control } \\
\text { Point (HACCP) }\end{array}$ & $2 \times 45^{\prime}$ \\
\hline $\begin{array}{ll}\text { C. Materi } \\
\text { penunjang }\end{array}$ & 15 & $\begin{array}{l}\text { Rangkuman } \\
\text { Hygiene sanitasi }\end{array}$ & $\begin{array}{l}\text { a. Ringkasan Materi } \\
\text { (Capita Selecta) } \\
\text { b. Latihan soal }\end{array}$ & $1 \times 45^{\prime}$ \\
\hline & 16 & Kepariwisataan & $\begin{array}{l}\text { a. Pengenalan } \\
\text { Pariwisata } \\
\text { b. Pariwisata Dalam } \\
\text { Pembangunan } \\
\text { c. Peran Makanan } \\
\text { Sehat Dalam } \\
\text { Pariwisata }\end{array}$ & $1 \times 45^{\prime}$ \\
\hline
\end{tabular}




\begin{tabular}{|l|l|l|l|c|}
\hline & $\mathbf{1 7}$ & $\begin{array}{l}\text { Manajemen } \\
\text { Hygiene sanitasi } \\
\text { Makanan }\end{array}$ & $\begin{array}{l}\text { a. Permodalan dan } \\
\text { Pemasaran } \\
\text { b. Peluang Bisnis dan } \\
\text { Motivasi Kerja } \\
\text { c. Organisasi dan } \\
\text { Asosiasi }\end{array}$ & $1 \times 45^{\prime}$ \\
\hline JUMLAH & & & & $\mathbf{3 5} \times \mathbf{4 5}$ \\
\hline
\end{tabular}

\section{F. KURIKULUM KURSUS HYGIENE SANITASI MAKANAN BAGI PENJAMAH MAKANAN}

\begin{tabular}{|c|c|c|c|c|}
\hline Bagian & No & Mata Pelajaran & Pokok Bahasan & $\begin{array}{c}\text { Jam } \\
\text { Pelajaran }\end{array}$ \\
\hline 1 & 2 & 3 & 4 & 5 \\
\hline A. Materi Dasar & 1 & $\begin{array}{l}\text { Peraturan } \\
\text { Perundang } \\
\text {-undangan Hygiene } \\
\text { sanitasi Makanan }\end{array}$ & $\begin{array}{l}\text { a.UU No. 23/1992 } \\
\text { tentang Kesehatan } \\
\text { b. Kepmenkes No. } \\
\text {.../2002 tentang } \\
\text { Persyaratan hygiene } \\
\text { sanitasi Makanan } \\
\text { Jajanan } \\
\text { c. Kepmenkes No. } \\
\text {.../2002 tentang } \\
\text { Persyaratan hygiene } \\
\text { sanitasi Rumah Makan / } \\
\text { Restoran } \\
\text { d. Kepmenkes No. ../2002 } \\
\text { tentang Persyaratan } \\
\text { Hygiene Sanitasi } \\
\text { Makanan jajanan }\end{array}$ & $2 \times 45^{\prime}$ \\
\hline B. Materi Inti & 2 & $\begin{array}{l}\text { Bahan Pencemar } \\
\text { Terhadap } \\
\text { Makanan }\end{array}$ & $\begin{array}{l}\text { a. Rantai Perjalanan } \\
\text { Makanan (Food } \\
\text { Chain) } \\
\text { b. Perkembangan Bakteri } \\
\text { Pada Makanan } \\
\text { c. Cara Bakteri } \\
\text { Menyebabkan } \\
\text { Penyakit Pada } \\
\text { Manusia } \\
\text { d. Mengenal pencemar } \\
\text { lain: virus, bahan } \\
\text { kimia, parasit, benda } \\
\text { asing dan bahan fisik. }\end{array}$ & $2 \times 45^{\prime}$ \\
\hline $\begin{array}{l}\text { D. Bahan } \\
\text { Pencemaran } \\
\text { Makanan }\end{array}$ & 3 & $\begin{array}{l}\text { Penyakit Bawaan } \\
\text { Makanan }\end{array}$ & $\begin{array}{l}\text { a. Penyebab oleh } \\
\text { mikroba } \\
\text { b. Penyebab oleh bahan } \\
\text { kimia } \\
\text { c. Penyebab Oleh Zat } \\
\text { Toksin }\end{array}$ & $1 \times 45^{\prime}$ \\
\hline
\end{tabular}




\begin{tabular}{|c|c|c|c|c|}
\hline & & & $\begin{array}{l}\text { d. Penyebab Oleh Zat } \\
\text { Alergi Penyakit }\end{array}$ & \\
\hline & 4 & Prinsip HSMM & $\begin{array}{l}\text { a. Sumber dan } \\
\text { b. Penyebaran Pencemar } \\
\text { Makanan } \\
\text { Pemilihan, } \\
\text { Penyimpanan, } \\
\text { Pengolahan, } \\
\text { Pengangkutan, } \\
\text { Penyajian dan } \\
\text { Konsumsi } \\
\text { c. Aspek Hygiene } \\
\text { Sanitasi } \\
\text { Makanan } \\
\text { d. Pengendalian } \\
\text { Waktu dan Suhu } \\
\text { Makanan (Danger } \\
\text { Zone) }\end{array}$ & $1 \times 45^{\prime}$ \\
\hline & 5 & $\begin{array}{l}\text { Pencucian dan } \\
\text { Penyimpanan } \\
\text { Peralatan } \\
\text { Pengolahan } \\
\text { Makanan }\end{array}$ & $\begin{array}{ll}\text { a. Peralatan Masak } \\
\text { Memasak } \\
\text { b. Peralatan Makan } \\
\text { Minum. } \\
\text { c. Sarana dan Cara } \\
\text { Pencucian } \\
\text { d. Bahan Pencuci } \\
\text { e. Penyimpanan } \\
\text { Peralatan } \\
\end{array}$ & $1 \times 45^{\prime}$ \\
\hline & & $\begin{array}{l}\text { Pemeliharaan } \\
\text { Kebersihan } \\
\text { Ling } \\
\text { kungan }\end{array}$ & $\begin{array}{l}\text { a. Air Bersih } \\
\text { b. Pembuangan Limbah } \\
\text { dan Sampah } \\
\text { c. Pengendalian } \\
\text { Serangga dan Tikus } \\
\text { d. Pemeliharaan dan } \\
\text { Pembersihan Ruangan } \\
\text { e. Fasilitas Sanitasi }\end{array}$ & $2 \times 45^{\prime}$ \\
\hline & & $\begin{array}{l}\text { Hygiene } \\
\text { Perorangan }\end{array}$ & $\begin{array}{ll}\text { a. } & \text { Sumber Pencemar dari } \\
\text { Tubuh } \\
\text { b. Pengamatan } \\
\text { Kesehatan } \\
\text { c. Pengetahuan, Sikap } \\
\text { dan } \\
\text { d. Perilaku Sehat. } \\
\text { e. Pakaian Pelindung } \\
\text { Pencemaran } \\
\end{array}$ & $1 \times 45^{\prime}$ \\
\hline JUMLAH & & & & $10 \times 45^{\prime}$ \\
\hline
\end{tabular}




\title{
SERTIFIKAT KURSUS HYGIENE SANITASI MAKANAN
}

\author{
NOMOR:
}

Berdasarkan kepada Kepmenkes Nomor. ... tahun 2003 tentang Persyaratan Hygiene Sanitasi Makanan Jajanan, telah dilaksanakan Evaluasi / Kursus Hygiene Sanitasi Makanan bagi pengusaha / penanggungjawab yang diselenggarakan oleh pada tanggal bertempat di Nomor......................, tanggal ...................., tentang Penetapan Peserta Yang dan sesuai dengan Keputusan Ketua Tim Evaluasi Lulus Evaluasi Kursus Hygiene Sanitasi Makanan, dengan ini memberikan sertifikat kepada :

\section{$\mathrm{Nam}$ a}

Tempat tanggal lahir

Al a m at

Pekerjaan / Jabatan

Perusahaan / Unit Kerja

Pemegang Sertifikat ini telah memenuhi syarat dan dipandang cakap untuk mengelola hygiene sanitasi makanan.

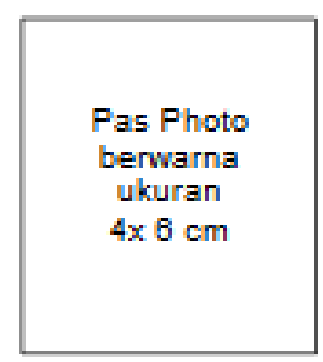




\section{HASIL EVALUASI HYGIENE SANITASI MAKANAN}

\section{MATERI PELAJIARAN YANG DIIKUTI}

\section{Kelompok Dasar :}

1. Perundang-undangan Hygiene Sanitasi Makanan

2. Persyaratan hygiene sanitasi Tempat Pengelolaan Makanan (TPM)

Kelompok Inti :

3. Bakteri Pencemar Terhadap Makanan

4. Bahan Pencemar Makanan Lainnya

5. Penyakit Bawaan Makanan

6. Prinsip Hygiene dan Sanitasi Makanan

7. Struktur dan Tata Letak Dapur

8. Pencucian dan Penyimpanan Peralatan Pengolahan Makanan

9. Pemeliharaan Kebersihan Lingkungan

10. Hygiene Perorangan

11. Penanganan Alat Pendingin

12. Proses Masak Memasak Makanan

13. Pengawetan dan Bahan Tambahan Mak:

14. Pengendalian Mutu Mandiri

Kelompok Penunjang :

KETUA TIM EVALUAS| KURSUS HYGIENE SANITASI MAKANAN

15.

16.

17.

NILAI EVALUASI RATA RAT A :

NIP. ) 


\title{
SERTIFIKAT KURSUS PENJAMAH MAKANAN
}

\author{
NOMOR:
}

Berdasarkan kepada Kepmenkes No. ... tahun 2003 tentang Persyaratan Hygiene Sanitasi Makanan jajanan, telah dilaksanakan Evaluasi / Kursus Hygiene Sanitasi Makanan bagi Penjamah Makanan yang diselenggarakan oleh , pada tanggal ..................................., bertempat di dan sesuai dengan Keputusan Ketua Tim Evaluasi No....................... tanggal ................... tentang Penetapan Peserta Yang Lulus Evaluasi Kursus Hygiene Sanitasi Makanan, dengan ini memberikan sertifikat kepada :

Nama

Tempat tanggal lahir

Alam at

Pekerjaan / Jabatan

Perusahaan / Unit Kerja

Pemegang Sertifikat ini telah memenuhi syarat dan dipandang cakap sebagai Penjamah makanan (food handler).

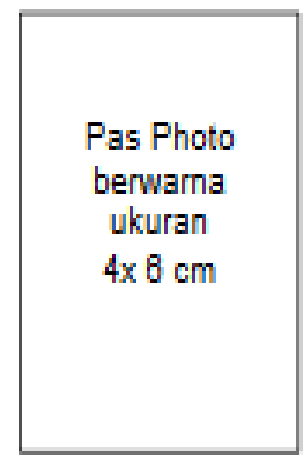




\section{HASIL EVALUASI HYGIENE SANITASI MAKANAN}

UATERI PELAJARAN YANG DIIKUTI

Kelompok Dasar :

1. Perundang-undangan di Bidang Hygiene Sanitasi Makanan

Kelompok Inti :

2. Bakteri Pencemar Terhadap Makanan

3. Penyakit Bawaan Makanan

4. Prinsip Hygiene dan Sanitasi Makanan

5. Pencucian dan Penyimpanan Peralatan Pengolahan Makanan

6. Pemeliharaan Kebersihan Lingkungan

7. Hygiene Perorangan

Kelompok Penunjang :

8.

9.

10

NILAI EVALUASI RATA RATA :

NIP.

KETUA TIM EVALUASI

KURSUS HYGIENE SANITASI MAKANAN

MENTERI KESEHATAN,

Dr. ACHMAD SUJUDI 


\section{DAFTAR PUSTAKA}

Anzarkusuma. I.C. Erry Y.M.,Idrus J. 2014. Status Gizi Berdasarkan Pola Makan Anak Sekolah Dasar di Kecamatan Rajeg Tangerang. Indonesian Journal of Human Nutrition. Vol.1(2): 136-148.

Aprillia, B.A. 2011. Faktor Yang Berhubungan Dengan Pemilihan Makanan Jajanan Pada Anak Usia Sekolah Dasar. http://eprints.undip.ac.id/32606/ 1/403_Bondika_Ariandani_april lia_G2C007016.pdf . Semarang : UNDIP. [diakses 8 Januari 2015].

Badan Pengawas Obat dan Makanan. (2011). Laporan Tahunan BPOM 2011. Jakarta: BPOM RI.

Badan Pengawas Obat dan Makanan. Komitment dan kemandirian komunitas sekolah sukseskan aksi nasional PJAS. InfoPOM. 2012

Balitbangkes. Laporan Nasional Riset Kesehatan Dasar Tahun 2010. Kementerian Kesehatan Republik Indonesia; 2010.

BPOM. (2104). Berita Keracunan Bulan JanuariMaret. Diakses dari http://ik.pom.go.id/v2014/berita-keracunan/kejadian-keracunanbulanjanuari-maret-2014.

Departemen Kesehatan Republik Indonesia. Keputusan Menteri Kesehatan Republik Indonesia Nomor 942/Menkes/SK/VII/2003 Tentang Pedoman Persyaratan Hygiene Sanitasi Makanan Jajanan. Kementerian Kesehatan Republik Indonesia; 2004

Farnsworth, BJ, Dunoskovich, JH. 2001. Consumer Skill Activities Kindergaten Through Sixth Grade. Education.

Fahyuni, Eni Fariyatul \& Istikomah (2016). Psikologi Belajar dan Mengajar (Kunci Sukses Guru dan Peserta Didik dalam Interaksi Edukatif). Sidoarjo: Nizamia Learning Center.

Fahyuni, Eni Fariyatul. 2017. Teknologi, Informasi, dan Komunikasi (Prinsip dan Aplikasi dalam Studi Pemikiran Islam). Sidoarjo: Umsida Press.

Kemenkes RI. (2014). Perilaku Mencuci Tangan Memakai Sabun di Indonesia. Jakarta Selatan: PusDatin. Kemenkes RI. (2003). Kepmenkes No. 1098/ MENKES/SK/VII/2003 tentang Persyaratan Higiene Sanitasi Rumah Makan dan Restoran. Diakses dari https://dinkes.sumselprov.go.id

Kurniadi, Y., Saam, Z., \& Afandi, D. (2013). Faktor Kontaminasi bakteri E. Coli pada Makanan Jajanan di Lingkungan Kantin Sekolah Dasar Wilayah Kecamatan Bangkinang. Jurnal Ilmu Lingkungan, 7 (1), 28-37. 
Mukono, 2000. Prinsip Dasar Kesehatan Lingkungan. Airlangga University Press, Surabaya.

Pratiwi, L.R. (2014). Hubungan Anatara Personal Hygiene dan Sanitasi Makanan Dengan Kandungan E. Coli pada Sambal yang Disediakan Kantin Universitas Negeri Semarang Tahun 2012. Unnes Journal of Public Health, (4),17-24.

Purnawijayanti, H.A. (2001). Sanitasi Higiene dan Keselamatan Kerja Dalam Pengolahan Makanan. Yogyakarta: Penerbit Kanisius.

Sulchan, M., \& Nur,, E.W. (2007). Keamanan Pangan Kemasan Plastik dan Styrofoam. Majalah Kedokteran Indonesia.

Syafirah,S. \& Andrias, Dini Ririn. Higiene Penjamah Makanan dan Sanitasi Kantin Sekolah Dasar Negeri di Kecamatan Mulyorejo. Surabaya. Media Gizi Indonesia, Vol. 10, No. 2 Juli-Desember 2012: hlm. 111-116

Winarno, F.G . 1993. Makanan Jajanan. Laporan Akhir Proyek Makanan jajanan. Bogor: Institut pertanian Bogor. 


\section{BIODATA PENULIS}

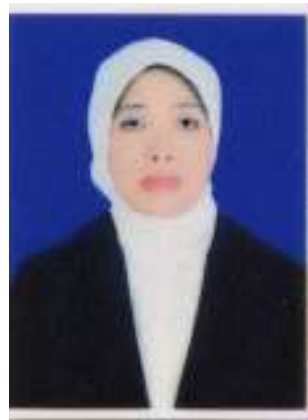

Eni Fariyatul Fahyuni merupakan seorang dosen di Fakultas Agama Islam, Universitas Muhammadiyah Sidoarjo yang mengampu beberapa mata kuliah diantaranya: profesi keguruan, ilmu kependidikan, bimbingan dan konseling, psikologi perkembangan, psikologi belajar, Kapita Selekta Pendidikan dan ICT pembelajaran. Putri ke-3 dari pasangan bapak H. Ach. Fithon dan Ibu Hj. Ismachu Djumroh ini lahir di Sidoarjo, 04 November 1978 yang mengawali kariernya sebagai konselor bimbingan dan konseling di SMK pada tahun 2011 hingga tahun 2014. Buku hasil karya yang sukses diterbitkan antara lain 1) Tahun 2016, buku Inovasi Model Pembelajaran Sesuai Kurikulum 2013; 2) Tahun 2016, buku Psikologi Belajar dan Mengajar (Kunci Sukses Guru dan Peserta Didik dalam Interaksi Edukatif); 3) Tahun 2017, buku Teknologi Informasi dan Komunikasi (Prinsip dan Aplikasi dalam Studi Pemikiran Islam), 4) tahun 2018, Kenapa Bisa Begini, Ya? Suhu dan Kalor, dan 5) Tahun 2018, buku ajar "Senangnya Bisa Bersedekah". Latar belakang pendidikan yang digelutinya adalah sarjana Universitas Islam Negeri Sunan Ampel Surabaya Program Studi Psikologi (2011) selanjutnya Pendidikan Islam Pascasarjana Universitas Muhammadiyah Sidoarjo (2013), dan saat ini penulis sedang menempuh studi Doktoral Program Studi Teknologi Pendidikan di Universitas Negeri Surabaya (UNESA).

\section{BIODATA PENULIS}

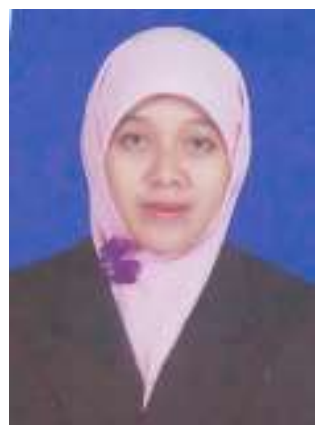

Anita Puji Astutik, lahir di Sidoarjo pada tanggal 21 Januari 1980. Dosen tetap Universitas Muhammadiyah Sidoarjo yang mengampu mata kuliah Al-Islam dan Kemuhamadiyahan dan mata kuliah Pendidikan Agama Islam ini memperoleh gelar kesarjanaan dari Fakultas Tarbiyah jurusan Pendidikan Agama Islam Institut Agama Islam Negeri Sunan Ampel Surabaya dengan predikat Cumlaude (2001). Aktifitas sosial keagamaan di organisasi Aisiyah dan partisipasi di tengah masyarakat serta menjadi praktisi di dunia pendidikan tidak melupakan dahaganya dengan dunia akademis. kegemarannya membaca dan berdiskusi mengantarkannya kembali ke bangku perkuliahan Pasca Sarjana Universitas Muhammadiyah Sidoarjo. Gelar M.PDI dari Universitas Muhammadiyah Sidoarjo diperoleh dengan predikat Cumlaude pada tahun 2013. Untuk memperdalam keilmuannya tentang Islam, Konsentrasi kajian Islam Kontemporer diambilnya dalam studi S3 di Universitas Islam Negeri Sunan Ampel Surabaya. 
